\title{
A multivariate approach based on physicochemical parameters and biological potential for the botanical and geographical discrimination of Brazilian bee pollen
}

\author{
Adriane Alexandre Machado De-Melo ${ }^{\mathrm{a}, *}$, Leticia M. Estevinho ${ }^{\mathrm{b}, \mathrm{c}}$, Manuela M. Moreira ${ }^{\mathrm{d}}$, \\ Cristina Delerue-Matos ${ }^{\mathrm{d}}$, Alex da Silva de Freitas ${ }^{\mathrm{e}}$, Ortrud Monika Barth ${ }^{\mathrm{f}, \mathrm{g}}$, \\ Ligia Bicudo de Almeida-Muradian ${ }^{\mathrm{a}}$

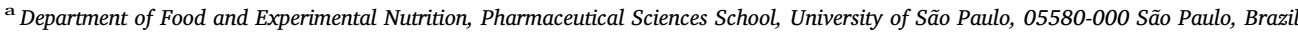 \\ b Agricultural College of Bragança, Polytechnic Institute of Bragança, Campus Santa Apolónia E, 5301-855 Bragança, Portugal \\ ${ }^{c}$ Centre of Molecular and Environmental Biology, University of Minho, Campus de Gualtar, 4710-057 Braga, Portugal \\ d REQUIMTE/LAQV, Superior Institute of Engineering, Polytechnic Institute of Porto, 4200-072 Porto, Portugal \\ e Laboratory of Marine Geology, Federal Fluminense University, 24210-340 Niterói, Brazil \\ ${ }^{\mathbf{f}}$ Laboratory of Palynology, Department of Geology, Institute of Geosciences, Federal University of Rio de Janeiro, 21949-900 Rio de Janeiro, RJ, Brazil \\ ${ }^{\mathrm{g}}$ Laboratory of Viral Morphology and Morphogenesis, Oswaldo Cruz Institute, Fiocruz, 21040-360 Rio de Janeiro, Brazil
}

\section{A R T I C L E I N F O}

\section{Keywords:}

Bee products

Chemical properties

Colour

Phenolic profile

Minerals

Chemometrics

\begin{abstract}
A B S T R A C T
Fifty six Brazilian bee pollen samples were characterised, and their botanical and geographical origins were studied. The samples were also classified based on physicochemical and biological properties. The characterisation was done using Soxhlet extraction and micro-Kjeldahl methods, ashing at $550{ }^{\circ} \mathrm{C}$, transmittance, microscopy, spectrophotometry, inductively coupled plasma optical emission spectrometry and high-performance liquid chromatography. As expected, the values of proteins (7.9-32.2 g/100 g), lipids (3.2-13.5 g/100 g), ash (1.9-3.6 g/100 g), carbohydrates $(54.9-82.8 \mathrm{~g} / 100 \mathrm{~g}), \mathrm{K}(3.4-9.8 \mathrm{~g} / \mathrm{kg}), \mathrm{Ca}(0.9-4.1 \mathrm{~g} / \mathrm{kg}), \mathrm{Mg}(0.6-2.4 \mathrm{~g} / \mathrm{kg})$, Fe (46-1180 mg/kg), Na (20-374 mg/kg), Mn (25-215 mg/kg), Zn (30-101 mg/kg), Cu (7.4-19.7 mg/kg), total phenolics (6.5-29.2 mg GAE/g) and flavonoids (0.3-17.5 mg QE/g) as well as the phenolic profiles varied among the samples. In general, the products had high antioxidant capacity (ORAC: 133-563 $\mu \mathrm{mol}$ TE/g; DPPH: 9.4-155 $\mu \mathrm{mol} \mathrm{TE} / \mathrm{g}$ ) and the antimicrobial capacity varied according to the sample and microorganism tested. The instrumental colour parameters could be used as indicators of some minerals. Based on multivariate approaches, bee pollen from Southern Brazil seemed to have a higher biological potential, whereas products from the Northeast region had higher calcium and magnesium levels. Similarities were identified in bee pollen containing C. nucifera or Brassica, and monofloral bee pollen seemed to have higher mineral content than heterofloral bee pollen.
\end{abstract}

\section{Introduction}

Bee pollen is the result of the agglutination of pollen grains harvested by Apis mellifera L. bees; therefore, its characteristics vary according to the pollen composition of each plant species. For the bee colony, it is a source of proteins, lipids, vitamins and minerals. For the consumer, it is a food with nutraceutical potential, which could aid in the prevention of disease because it contains bioactive substances (Campos et al., 2008; De-Melo \& Almeida-Muradian, 2017; Komosinska-Vassev, Olczyk, Kafmierczak, Mencner, \& Olczyk, 2015).
Many polyphenols have antioxidant, antimicrobial, anti-inflammatory, anxiolytic, antiarterosclerosis, antimutagenic, and cardioprotective potential. These compounds are present in pollen grains and, consequently, in bee pollen (De-Melo \& Almeida-Muradian, 2017).

In the last few years, characterisation studies have been done by Brazilian researchers (Carpes et al., 2008; De-Melo et al., 2016, 2018; Morgano et al., 2010, 2012; Sattler et al., 2016); however, the composition of bee pollen marketed by many beekeepers remains unknown. The interest of the population for the regular consumption of natural products is increasing, but the consumer has been searching for high-

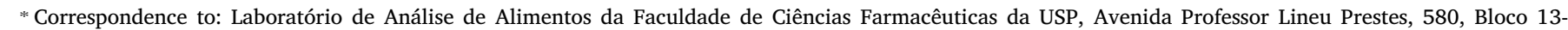
A, Cidade Universitária, 05580-000 São Paulo, SP, Brazil.

E-mail address: adriane.melo@uol.com.br (A.A.M. De-Melo). 
quality foods with specific properties (Aschemann-Witzel, 2015). To meet this demand, it would be necessary to not only characterise the bee pollen produced in Brazil but also identify what properties are related to its botanical and geographical origin. In this sense, the use of multivariate statistical techniques would enable the simultaneous analysis of large data sets and the identification of trends in the samples or groups.

Based on the above, the aim of the present study was to determine physicochemical and biological properties of 56 dehydrated bee pollen samples produced in 9 states of 4 Brazilian regions to identify correlations between the results and the botanical as well as geographical origins of the samples; and to classify the products based on some variables. Based on current literature, this is the first study carried out with so many Brazilian samples and analyses that uses a multivariate approach to provide more accurate interpretation of the results and to study the botanical and geographical origin of the samples.

\section{Material and methods}

\subsection{General}

All chemicals (acetone, aluminium nitrate, boric acid, hydrochloric acid, copper sulphate pentahydrate, ethanol, ethyl ether, formic acid, glycerine, methanol, nitric acid, perchloric acid, potassium acetate, potassium sulphate, sodium carbonate, sodium chloride, sodium hydroxide, sodium phosphate, and sulphuric acid) were of analytical-reagent grade and were purchased from Synth (São Paulo, SP, Brazil).

Phenolic standards ( $\beta$-resorcylic acid, $p$-coumaric acid, caffeic acid, catechin, chlorogenic acid, cinnamic acid, epicatechin, ferulic acid, gallic acid, kaempferol, naringin, naringenin, protocatechic acid, quercetin, rutin, synapic acid, syringic acid, and vanillic acid), 1,1-diphenyl-2-picrylhydrazyl (DPPH); 2,2'-azobis(2-methylpropionamidine) dihydrochloride (AAPH); 2,3,5-triphenyl-tetrazolium chloride (TCC) solution; 6-hydroxy-2,5,7,8-tetramethylchromane-2-carboxylic acid (Trolox); dimethyl sulfoxide; fluorescein; fluconazole; FolinCiocalteau's phenol reagent; gentamicin; glycerol; Müeller Hinton medium; nutrient broth; and yeast nitrogen base were purchased from Sigma-Aldrich (St. Louis, MO, USA). Mineral standards (Fe, $\mathrm{Cu}, \mathrm{Ca}, \mathrm{Mg}$, $\mathrm{Zn}, \mathrm{Mn}, \mathrm{Na}$ and $\mathrm{K}$ ) were purchased from AccuStandard (São Paulo, SP, Brazil), and dimethyl sulfoxide (DMSO) from Riedel-de Haën (Bucharest, Romania).

The following equipment were used: an A11 analytical mill (SigmaAldrich); a nitrogen distiller (Tecnal, São Paulo, SP, Brazil); a digester block (Quimis, São Paulo, SP, Brazil); a fat determination system (Tecnal); an oven (Quimis); a water bath (Fisaton, São Paulo, SP, Brazil); an ICP-OES spectrometer (Ciros Vision EOP, Spectro, Kleve, Germany); ColorQuest XE spectrophotometer with Universal Software V4.10 (Hunterlab, Reston, VA, USA); a rotary evaporator with a vacuum system (Buchi, RE-111 and B-461, Flawil, Switzerland); a Synergy $^{\mathrm{TM}}$ HT multi-detection microplate reader (BioTek Instruments, Winooski, VT, USA); a Shimadzu UV 1650 PC spectrophotometer (Kyoto, Japan) - to determine total phenolics, total flavonoids and antioxidant capacity; a Varian UV-Visible Cary 50 Scan spectrophotometer (Agilent Technologies, Santa Clara, CA, USA) - to determine antimicrobial capacity; a Shimadzu HPLC system (Software LabSolutions, Kyoto, Japan), with a column oven (CTO-10AS VP), an injection system (LC-20AD), an autosampler (SIL-20A HT) and a photodiode array detector (PDA) (SPD-M20A), and equipped with a Gemini $\mathrm{C}_{18}$ reversed-phase column $(250 \times 4.6 \mathrm{~mm}, 5 \mu \mathrm{m})$ protected by a guard column of the same material (Phenomenex, Torrance, CA, USA) - for HPLC analysis.

\subsection{Bee pollen samples}

A total of 56 bee pollen samples were received between December 2011 and December 2013. They were collected in apiaries from 9 states (Sergipe, Bahia, Rio Grande do Norte, São Paulo, Rio Grande do Sul, Santa Catarina, Paraná, Mato Grosso, Mato Grosso do Sul) located in 4 Brazilian regions (Northeast, Southeast, Southern, Central-West). The samples had been produced by Apis mellifera $\mathrm{L}$. bees and processed by beekeepers or food companies. Processing included a dehydration step at temperatures between 40 and $50{ }^{\circ} \mathrm{C}$. The products were sent to the Laboratory of Food Analysis (LFA) of the Faculty of Pharmaceutical Sciences, University of São Paulo (São Paulo, SP, Brazil) at $25 \pm 3{ }^{\circ} \mathrm{C}$, and they were coded. The geographical origin and collection date of the samples are shown in Table 1.

A part of the experiment was done in the Laboratory of Microbiology (LM) of the Polytechnic Institute of Bragança (Bragança, Portugal); a part, in the Laboratory of Palynology (LP) of the Federal University of Rio de Janeiro (Rio de Janeiro, RJ, Brazil); and another part, in the Centre for Agricultural and Environmental Technology (CAET) (Porangatu, SP, Brazil). The bee pollen samples were sent to the laboratories at room temperature and then stored at $-4{ }^{\circ} \mathrm{C}$ in a freezer (LFA and LM) or at room temperature (LP and CAET). Immediately before each analysis, the samples were taken from the freezer, allowed to reach room temperature, crushed in the analytical mill, and sieved through a $0.595 \mathrm{~mm}$ sieve. Only for the preparation of the methanolic extracts and for the palynological evaluation the samples were not crushed. For the methanolic extracts the samples were left to macerate as proposed by Morais, Moreira, Feás, and Estevinho (2011), and for the palynological evaluation the bee pollen should be intact for identification of the pollen grains.

\subsection{Palynological evaluation}

The pollen analysis was done as described by Barth et al. (2010). At least 500 pollen grains per sample were identified based on pollen catalogues and other studies (Barth, 1970a, 1970b, 1970c, 1989; Moreti, Marchini, Souza, \& Rodrigues, 2002). The identified pollen grains were counted to determine the frequency of each pollen type. The frequency was presented as a percentage (\%). The pollen types were classified into predominant pollen (PLP, $>45 \%$ of pollen grains), accessory pollen (AP, from $16 \%$ to $45 \%$ ) or important isolated pollen (IP, from $3 \%$ to $15 \%$ ). Samples with more than 90 , or $60 \%$ or more of a pollen type without the occurrence of AP were classified as monofloral; the other samples were classified as heterofloral.

\subsection{Physicochemical parameters}

Lipid content was determined using Soxhlet extraction (AlmeidaMuradian, Arruda, \& Barreto, 2012; Method 945.38 AOAC, 2005), based on lipid extraction using diethyl ether from $2 \mathrm{~g}$ of sample for $8 \mathrm{~h}$, replacing the solvent when necessary for total immersion of the sample. The micro-Kjeldahl method was used to determine the nitrogen content from $100 \mathrm{mg}$ of material, whose value was converted to protein content using a factor of 6.25 (Almeida-Muradian et al., 2012; Method 979.09 AOAC, 2005). Ash was determined by incineration of the samples in an oven at $550{ }^{\circ} \mathrm{C}$ for $8 \mathrm{~h}$ (Almeida-Muradian et al., 2012; Method 945.38 AOAC, 2005).

$\mathrm{Fe}, \mathrm{Cu}, \mathrm{Ca}, \mathrm{Mg}, \mathrm{Zn}, \mathrm{Mn}, \mathrm{Na}$ and $\mathrm{K}$ were extracted from $500 \mathrm{mg}$ of sample using acid digestion (nitric acid: perchloric acid, 2:1, mL:mL) in an open system (Malavolta et al., 1997), and then, the minerals were determined by inductively coupled plasma optical emission 
Table 1

Geographical origin, collection date, classification (monofloral or heterofloral) and relative frequency (\%) of the pollen types (botanical taxa) of 56 Brazilian bee pollen samples produced in 9 states from 4 regions.

\begin{tabular}{|c|c|c|c|c|c|}
\hline \multirow[t]{2}{*}{ Sample ${ }^{a}$} & \multicolumn{2}{|c|}{ Geographical origin } & \multirow[t]{2}{*}{ Collection date } & \multicolumn{2}{|l|}{ Botanical origin } \\
\hline & Region & State & & Classification $^{\mathrm{b}}$ & Pollen types and (frequency) ${ }^{c}$ \\
\hline A1 & Northeast & Sergipe & 12-20/Apr/12 & $\begin{array}{l}\text { Monofloral of Mimosa } \\
\text { caesalpiniifolia }\end{array}$ & $\begin{array}{l}\text { PP: } \text { M. caesalpiniifolia }(95.5 \%) \\
\text { IP: } \text { Cocos nucifera }(3.5 \%)\end{array}$ \\
\hline B1 & & Bahia & 10/May/12 & Heterofloral & $\begin{array}{l}\text { PP: C. nucifera }(59.9 \%) \text {; } \\
\text { AP: Mimosa scabrella }(21 \%) \text {; } \\
\text { IP: Eucalyptus }(14.2 \%) \text {; Asteraceae }(3.8 \%)\end{array}$ \\
\hline $\mathrm{C} 1$ & & Bahia & 01/Aug/12 & Heterofloral & $\begin{array}{l}\text { PP: } \text { C. nucifera }(56.7 \%) \text {; } \\
\text { AP: } \text { M. caesalpiniifolia }(20.6 \%) \text {; Eucalyptus }(15.5 \%) \text {; } \\
\text { IP: Unidentified ( } 3.3 \%)\end{array}$ \\
\hline $\mathrm{C} 2$ & & Bahia & 19/Jun/12 & Heterofloral & $\begin{array}{l}\text { PP: Eucalyptus }(63.4 \%) \text {; } \\
\text { AP: } \text { M. caesalpiniifolia }(25.8 \%) \text {; } \\
\text { IP: } \text { C. } \text { nucifera }(3 \%)\end{array}$ \\
\hline $\mathrm{C} 3$ & & Bahia & 16/Sep/12 & Monofloral of Eucalyptus & $\begin{array}{l}\text { PP: Eucalyptus ( } 86.5 \%) \text {; } \\
\text { IP: C. nucifera (7.5\%); Eupatorium (3.7\%) }\end{array}$ \\
\hline $\mathrm{C} 4$ & & Bahia & 06/Oct/12 & Heterofloral & $\begin{array}{l}\text { PP: } \text { M. caesalpiniifolia }(55.4 \%) \\
\text { AP: } \text { Eucalyptus }(35.6 \%) \\
\text { IP: } \text { C. } \text { nucifera }(4.5 \%)\end{array}$ \\
\hline C5 & & Bahia & 12/Aug/12 & Heterofloral & $\begin{array}{l}\text { PP: Eucalyptus }(57.2 \%) \text {; } \\
\text { AP: Coffea }(24.4 \%) \text {; } \\
\text { IP: C. nucifera }(7.6 \%) \text {; Asteraceae }(7.6 \%)\end{array}$ \\
\hline $\mathrm{C} 6$ & & Bahia & $23 / \mathrm{Sep} / 12$ & Heterofloral & $\begin{array}{l}\text { PP: Coffea }(49.9 \%) \\
\text { AP: C. nucifera }(22.4 \%) \text {; } \\
\text { IP: Eupatorium }(11.2 \%) ; \text { Myrcia }(4.9 \%) \text {; Poaceae }(3.7 \%)\end{array}$ \\
\hline $\mathrm{C} 7$ & & Bahia & $23 / \mathrm{Jul} / 12$ & Monofloral of Rubiaceae & $\begin{array}{l}\text { PP: Rubiaceae (77.9\%); } \\
\text { IP: Eucalyptus (11.2\%); M. caesalpiniifolia (10.6\%); C. nucifera }(8.4 \%)\end{array}$ \\
\hline D1 & & Bahia & 21/Jun/12 & Heterofloral & $\begin{array}{l}\text { AP: } \text { M. caesalpiniifolia (29.1\%); Arecaceae }(26.4 \%) \text {; Cecropia }(19.1 \%) \text {; } \\
\text { IP: Unidentified }(11.8 \%)\end{array}$ \\
\hline E1 & & Bahia & $28 /$ Nov/12 & $\begin{array}{l}\text { Monofloral of Astrocaryum } \\
\text { aculeatissimum }\end{array}$ & $\begin{array}{l}\text { PP: A. aculeatissimum (71.9\%); } \\
\text { IP: Astronium (13.4\%); M. caesalpiniifolia (7.3\%); Mimosa verrucosa }(6.1 \%)\end{array}$ \\
\hline E2 & & Bahia & $11 / \mathrm{Feb} / 13$ & Monofloral of Fabaceae & $\begin{array}{l}\text { PP: Fabaceae (89.2\%); } \\
\text { IP: Myrtaceae (3.8\%); Unidentified (3.8\%) }\end{array}$ \\
\hline F1 & & Bahia & $\begin{array}{l}\text { 26/Apr to 04/May/ } \\
13\end{array}$ & Monofloral of $C$. nucifera & $\begin{array}{l}\text { PP: } \text { C. nucifera }(91.7 \%) \\
\text { IP: } \text { M. caesalpiniifolia }(6.1 \%)\end{array}$ \\
\hline G1 & & Bahia & $\begin{array}{l}25 / \text { Apr to } 01 / \text { May/ } \\
13\end{array}$ & Heterofloral & AP: Eucalyptus (36.2\%); M. caesalpiniifolia (36.2\%); C. nucifera (27.6\%) \\
\hline $\mathrm{H} 1$ & & Bahia & Jun/13 & Monofloral of $C$. nucifera & $\begin{array}{l}\text { PP: C. nucifera }(86.5 \%) \\
\text { IP: } \text { M. scabrella }(12.4 \%)\end{array}$ \\
\hline I1 & & Bahia & Jun/13 & Heterofloral & $\begin{array}{l}\text { PP: C. nucifera }(65.7 \%) \text {; } \\
\text { AP: } \text { M. scabrella }(20.9 \%) \text {; } \\
\text { IP: Asteraceae }(7.5 \%)\end{array}$ \\
\hline $\mathrm{J} 1$ & & $\begin{array}{l}\text { Rio Grande do } \\
\text { Norte }\end{array}$ & $25 / \mathrm{Sep} / 12$ & Heterofloral & $\begin{array}{l}\text { PP: } \text { M. scabrella }(79.7 \%) \text {; } \\
\text { AP: } \text { M. caesalpiniifolia }(15.6 \%) \text {; } \\
\text { IP: } \text { M. verrucosa }(4.3 \%)\end{array}$ \\
\hline K1 & & $\begin{array}{l}\text { Rio Grande do } \\
\text { Norte }\end{array}$ & 05/Oct/12 & Monofloral of $M$. verrucosa & $\begin{array}{l}\text { PP: } \text { M. verrucosa }(84.3 \%) \text {; } \\
\text { IP: C. nucifera }(10.5 \%) ; \text { Richardia }(3.4 \%)\end{array}$ \\
\hline L1 & Southeast & São Paulo & Sep/12 & Heterofloral & $\begin{array}{l}\text { PP: Eupatorium }(57.6 \%) \\
\text { AP: Piper }(30.3 \%) ; \\
\text { IP: Elephantopus }(7.8 \%)\end{array}$ \\
\hline M1 & & São Paulo & 03/Sep/12 & Heterofloral & $\begin{array}{l}\text { PP: Syagrus (62.8\%); } \\
\text { IP: Eupatorium (13.5\%); Myrcia (10.8\%); Cecropia }(9.9 \%)\end{array}$ \\
\hline M2 & & São Paulo & 18/Sep/12 & Heterofloral & $\begin{array}{l}\text { PP: Syagrus }(63.6 \%) \text {; } \\
\text { AP: Fabaceae }(21.5 \%) \text {; } \\
\text { IP: Vernonia }(5.1 \%)\end{array}$ \\
\hline M3 & & São Paulo & 03/Oct/12 & Monofloral of A. aculeatissimum & $\begin{array}{l}\text { PP: A. aculeatissimum (66\%); } \\
\text { IP: Ilex (13\%); Vernonia }(10.1 \%)\end{array}$ \\
\hline M4 & & São Paulo & 16/Oct/12 & Heterofloral & $\begin{array}{l}\text { PP: Eupatorium }(50.3 \%) \\
\text { AP: Syagrus }(41 \%) \\
\text { IP: Vernonia }(6.3 \%)\end{array}$ \\
\hline M5 & & São Paulo & $16-25 / \mathrm{Oct} / 12$ & Monofloral of Myrcia & $\begin{array}{l}\text { PP: Myrcia (66.4\%); } \\
\text { IP: Ilex (13.3\%); Syagrus (13.3\%); Cecropia (6\%) }\end{array}$ \\
\hline M6 & & São Paulo & $\begin{array}{l}25 / \mathrm{Oct} \text { to } 08 / \mathrm{Nov} / \\
12\end{array}$ & Heterofloral & $\begin{array}{l}\text { AP: Piper (39\%); Cecropia (27.1\%); } \\
\text { IP: Myrcia (14.1\%); Schinus (12.8\%); Syagrus (3.7\%) }\end{array}$ \\
\hline M7 & & São Paulo & $14-19 /$ Nov/12 & Heterofloral & $\begin{array}{l}\text { AP: Piper (38.6\%); A. aculeatissimum }(34.7 \%) \\
\text { IP: Cecropia }(14.5 \%) ; \text { Ilex }(5.8 \%)\end{array}$ \\
\hline M8 & & São Paulo & $\begin{array}{l}20 / \text { Nov to } 04 / \mathrm{Dec} / \\
12\end{array}$ & Heterofloral & $\begin{array}{l}\text { PP: Cecropia }(50.9 \%) \\
\text { AP: } \text { Myrcia }(30.3 \%) \\
\text { IP: Piper }(12.9 \%)\end{array}$ \\
\hline M9 & & São Paulo & 06-13/Dec/12 & Heterofloral & $\begin{array}{l}\text { PP: Arecaceae }(74.2 \%) \\
\text { AP: Cecropia }(18.8 \%)\end{array}$ \\
\hline
\end{tabular}


Table 1 (continued)

\begin{tabular}{|c|c|c|c|c|c|}
\hline \multirow[t]{2}{*}{ Sample ${ }^{a}$} & \multicolumn{2}{|c|}{ Geographical origin } & \multirow[t]{2}{*}{ Collection date } & \multicolumn{2}{|l|}{ Botanical origin } \\
\hline & Region & State & & Classification $^{\mathrm{b}}$ & Pollen types and (frequency) ${ }^{c}$ \\
\hline M10 & & São Paulo & $08-15 / \operatorname{Jan} / 13$ & Heterofloral & $\begin{array}{l}\text { PP: C. nucifera }(68 \%) \text {; } \\
\text { AP: Cecropia }(15.3 \%) \text {; } \\
\text { IP: Myrcia }(8.8 \%) ; \text { M. caesalpiniifolia }(4.3 \%)\end{array}$ \\
\hline M11 & & São Paulo & $18-25 / \mathrm{Jan} / 13$ & Heterofloral & AP: Arecaceae (37.9\%); M. caesalpiniifolia (29.7\%); Cecropia (18.5\%) \\
\hline N1 & & São Paulo & Aug-Sep/12 & Heterofloral & $\begin{array}{l}\text { AP: Anadenanthera }(40.5 \%) \text {; C. nucifera }(36.5 \%) \text {; } \\
\text { IP: } \text { M. scabrella }(13.5 \%) \text {; Malvaceae }(8.1 \%)\end{array}$ \\
\hline $\mathrm{N} 2$ & & São Paulo & 01-26/May/13 & Heterofloral & $\begin{array}{l}\text { AP: Alternanthera }(43.2 \%) \text {; M. caesalpiniifolia }(29.6 \%) \text {; } \\
\text { IP: Ricinus }(13.5 \%) \text {; Asteraceae (4.9\%); Poaceae }(3.9 \%)\end{array}$ \\
\hline N3 & & São Paulo & $\begin{array}{l}27 / \text { May to } 07 / \text { Jun/ } \\
13\end{array}$ & Monofloral of Alternanthera & PP: Alternanthera (93.3\%) \\
\hline N4 & & São Paulo & $\begin{array}{l}08 / \mathrm{Jul} \text { to } 04 / \mathrm{Aug} / \\
13\end{array}$ & Heterofloral & $\begin{array}{l}\text { PP: Alternanthera }(78.9 \%) \text {; } \\
\text { AP: Vernonia }(18.7 \%)\end{array}$ \\
\hline N5 & & São Paulo & 05-29/Aug/13 & Monofloral of Alternanthera & $\begin{array}{l}\text { PP: Alternanthera }(94 \%) \\
\text { IP: Montanoa }(3.4 \%)\end{array}$ \\
\hline $\mathrm{O} 1$ & & São Paulo & Sep/13 & Monofloral of Asteraceae & $\begin{array}{l}\text { PP: Asteraceae (63.3\%); } \\
\text { IP: C. nucifera (14\%); Machaerium (13\%); Montanoa (9.4\%); Ilex (9\%); } \\
\text { Myrcia (9\%); Unidentified (6\%); Antigonon (4.2\%) }\end{array}$ \\
\hline $\mathrm{O} 2$ & & São Paulo & Nov/13 & Heterofloral & $\begin{array}{l}\text { PP: Brassica (49.2\%); } \\
\text { IP: Asteraceae (11.6\%); Unidentified (9.4\%); Montanoa (6\%); Ilex (9\%); } \\
\text { Myrcia (9\%); Apiaceae (3.9\%) }\end{array}$ \\
\hline $\mathrm{O} 3$ & & São Paulo & Dec/13 & Heterofloral & $\begin{array}{l}\text { PP: Brassica (44.8\%); } \\
\text { IP: Montanoa (13.2\%); Anacardiaceae (8.4\%); Asteraceae (10.5\%); Myrcia } \\
(6.6 \%)\end{array}$ \\
\hline P1 & & São Paulo & Dec/12 & Heterofloral & $\begin{array}{l}\text { AP: Brassica (25.1\%); M. caesalpiniifolia (22.7\%); } \\
\text { IP: C. nucifera (14.1\%); Asteraceae (7.1\%); M. scabrella }(5.7 \%)\end{array}$ \\
\hline P2 & & São Paulo & Jun/13 & Heterofloral & $\begin{array}{l}\text { AP: } \text { M. caesalpiniifolia (42\%); Myrcia }(18.6 \%) \\
\text { IP: Baccharis }(8.1 \%) \text {; Brassica }(5.8 \%) ; \text { C. nucifera }(4.2 \%)\end{array}$ \\
\hline Q1 & Southern & Paraná & 14/Sep/12 & Heterofloral & $\begin{array}{l}\text { PP: } \text { M. scabrella }(63.5 \%) \\
\text { AP: Brassica }(36.5 \%)\end{array}$ \\
\hline R1 & & Paraná & May/13 & Heterofloral & $\begin{array}{l}\text { PP: } \text { M. scabrella }(53.8 \%) \text {; } \\
\text { AP: Asteraceae }(17.5 \%) ; \\
\text { IP: Arecaceae }(9.4 \%) ; \text { Myrcia }(5.4 \%) \text {; Poaceae }(5.4 \%) \text {; Fabaceae }(5.4 \%)\end{array}$ \\
\hline R2 & & Paraná & Dec/13 & Heterofloral & $\begin{array}{l}\text { AP: Anacardiaceae }(30.4 \%) \text {; Fabaceae }(29.7 \%) ; \text { M. verrucosa }(20.3 \%) \\
\text { IP: Loranthaceae }(12.5 \%)\end{array}$ \\
\hline S1 & & Paraná & Nov/13 & Heterofloral & $\begin{array}{l}\text { PP: Myrcia }(51.4 \%) \text {; } \\
\text { AP: Machaerium }(33.7 \%) \text {; } \\
\text { IP: Schinus }(7.4 \%) ; \text { Brassica }(3.2 \%)\end{array}$ \\
\hline $\mathrm{T} 1$ & & $\begin{array}{l}\text { Rio Grande do } \\
\text { Sul }\end{array}$ & 05/Oct/12 & Heterofloral & $\begin{array}{l}\text { PP: Anadenanthera }(56.3 \%) \text {; } \\
\text { AP: Eucalyptus }(28.6 \%) \text {; Cecropia }(11 \%)\end{array}$ \\
\hline $\mathrm{T} 2$ & & $\begin{array}{l}\text { Rio Grande do } \\
\text { Sul }\end{array}$ & $25 /$ Oct/12 & Monofloral of Anadenanthera & $\begin{array}{l}\text { PP: Anadenanthera }(89.9 \%) \text {; } \\
\text { IP: Sebastiania }(6.9 \%) \\
\text { Asteraceae }(3.2 \%)\end{array}$ \\
\hline $\mathrm{T} 3$ & & $\begin{array}{l}\text { Rio Grande do } \\
\text { Sul }\end{array}$ & 15/Nov/12 & Heterofloral & $\begin{array}{l}\text { PP: Anadenanthera }(64.7 \%) \text {; } \\
\text { AP: Cecropia }(17 \%) ; \\
\text { IP: Sebastiania }(14.6 \%)\end{array}$ \\
\hline $\mathrm{T} 4$ & & $\begin{array}{l}\text { Rio Grande do } \\
\text { Sul }\end{array}$ & 05/Dec/12 & Heterofloral & $\begin{array}{l}\text { AP: Cecropia (27.2\%); Anadenanthera (25.4\%); Sebastiania (18.5\%); } \\
\text { Eucalyptus }(12.3 \%)\end{array}$ \\
\hline $\mathrm{U} 1$ & & $\begin{array}{l}\text { Rio Grande do } \\
\text { Sul }\end{array}$ & $15-30 / \mathrm{Oct} / 12$ & Heterofloral & $\begin{array}{l}\text { PP: Schinus }(46 \%) \\
\text { AP: } \text { Ilex }(34.8 \%) ; \\
\text { IP: Asteraceae }(11.7 \%) ; \text { Myrcia }(6.2 \%)\end{array}$ \\
\hline $\mathrm{U} 2$ & & $\begin{array}{l}\text { Rio Grande do } \\
\text { Sul }\end{array}$ & $\begin{array}{l}25 / \mathrm{Nov} \text { to } 10 / \mathrm{Dec} / \\
12\end{array}$ & Monofloral of Myrcia & $\begin{array}{l}\text { PP: Myrcia }(92.5 \%) \\
\text { IP: Eupatorium }(6 \%)\end{array}$ \\
\hline V1 & & $\begin{array}{l}\text { Rio Grande do } \\
\text { Sul }\end{array}$ & 05/May/12 & Monofloral of Brassica & $\begin{array}{l}\text { PP: Brassica ( } 84.6 \%) \text {; } \\
\text { IP: Asteraceae }(11.7 \%) \text {; } \\
\text { Eucalyptus }(3.4 \%)\end{array}$ \\
\hline V2 & & $\begin{array}{l}\text { Rio Grande do } \\
\text { Sul }\end{array}$ & $28 / \mathrm{Jun} / 12$ & Monofloral of Brassica & $\begin{array}{l}\text { PP: Brassica }(87.2 \%) \text {; } \\
\text { IP: }(10.5 \%)\end{array}$ \\
\hline V3 & & $\begin{array}{l}\text { Rio Grande do } \\
\text { Sul }\end{array}$ & 28/Jul/12 & Heterofloral & $\begin{array}{l}\text { PP: Brassica }(67.6 \%) \text {; } \\
\text { AP: Eucalyptus }(18 \%) \text {; } \\
\text { IP: Asteraceae }(12 \%)\end{array}$ \\
\hline W1 & & Santa Catarina & 2011 & Monofloral of Brassica & $\begin{array}{l}\text { PP: Brassica }(91.3 \%) \\
\text { IP: Montanoa }(5.4 \%)\end{array}$ \\
\hline $\mathrm{X} 1$ & Central-West & Mato Grosso & 2012 & Monofloral of Brassica & $\begin{array}{l}\text { PP: Brassica }(87.3 \%) \text {; } \\
\text { IP: C. nucifera }(5.3 \%) \text {; } \\
\text { Asteraceae }(4 \%)\end{array}$ \\
\hline Y1 & & $\begin{array}{l}\text { Mato Grosso do } \\
\text { Sul }\end{array}$ & 05/Sep/13 & Heterofloral & $\begin{array}{l}\text { PP: Fabaceae }(57.2 \%) \text {; } \\
\text { AP: Anadenanthera }(28.6 \%) \text {; } \\
\text { IP: Melastomataceae }(5 \%) \text {; } \\
\text { Ricinus }(5 \%) \text {; Cecropia }(3.7 \%)\end{array}$ \\
\hline
\end{tabular}

\footnotetext{
a The same letters indicate samples collected in the same apiary, and numbers indicate the lot;

b Monofloral: more than 90, or $60 \%$ or more of a pollen type without the occurrence of accessory pollen; Heterofloral: not classified as monofloral;

c PP: predominant pollen (> 45\%); AP: accessory pollen (15 to 45\%); IP: important isolated pollen ( 3 to $15 \%$ ).
} 
spectrometry as described by Morgano et al. (2012). The following parameters were used: forward power of $1.45 \mathrm{~kW}$, a cooling air-flow rate of $12 \mathrm{~L} / \mathrm{min}$; auxiliary argon flow of $1 \mathrm{~L} / \mathrm{min}$ argon (argon grade 6.0, purity $99.9999 \%$ ), a nebuliser air flow rate of $1 \mathrm{~L} / \mathrm{min}$ and a sample flow rate of $2 \mathrm{~mL} / \mathrm{min}$. The wavelengths were specific for each element (Fe: $238.2 \mathrm{~nm}, \mathrm{Cu}: 327.4 \mathrm{~nm}, \mathrm{Ca}: 422.7 \mathrm{~nm}, \mathrm{Mg}: 279.5 \mathrm{~nm}, \mathrm{Zn}$ : $213.9 \mathrm{~nm}, \mathrm{Mn}: 257.6 \mathrm{~nm}$, Na: $588.9 \mathrm{~nm}, \mathrm{~K}: 766.5 \mathrm{~nm}$ ), and a calibration curve was prepared for each mineral.

The instrumental colour parameters (Lab) were determined by transmittance on the colour difference meter using the CIE $L^{*}{ }^{*}{ }^{*}{ }^{*}$ system ( $\mathrm{L}^{*}$ : lightness, $\mathrm{a}^{*}$ : - blue to + red, and $\mathrm{b}^{*}$ : - green to + yellow), and Chroma $(\mathrm{C})$ was calculated $\left[\left(\mathrm{a}^{*^{2}}+\mathrm{b}^{*^{2}}\right)^{1 / 2}\right]$. An illuminant D65 and an observation angle of $10^{\circ}$ were used. The samples were analysed in a $50 \mathrm{~mm}$ quartz cuvette, at room temperature.

\subsection{Preparation of extracts}

Ethanolic and methanolic extracts were prepared to determine the antioxidant and antimicrobial capacity of the bee pollen samples. The ethanolic extracts (ETE) were obtained as described by Carpes et al. (2008), considering the modifications proposed by De-Melo et al. (2016), e.g., $2 \mathrm{~g}$ of bee pollen samples in $25 \mathrm{~mL}$ of $70 \%$ ethanol solution, at $70{ }^{\circ} \mathrm{C}$ in a water bath for $30 \mathrm{~min}$ with constant agitation $(105 \mathrm{rpm})$. The procedure described by Morais et al. (2011) was adopted to prepare the methanolic extracts (MEE): sample and methanol were mixed (1:2, $\mathrm{g}: \mathrm{mL}$ ) and left to macerate for $72 \mathrm{~h}$ at room temperature, and then, the solid residue was re-extracted. The two extracts were combined. A rotary evaporator with a vacuum system was used at $45^{\circ} \mathrm{C}$ to completely evaporate the methanol. All extractions were done in a triplicate.

\subsection{Total phenolic and flavonoids}

The procedures described by Carpes et al. (2008), with the modifications proposed by De-Melo et al. (2016), were used for the analysis. The ETE $(100 \mu \mathrm{L})$ were diluted in $2.5 \mathrm{~mL}$ of $70 \%$ ethanol solution, and the total phenolic content was determined using the Folin-Ciocalteau reagent $(2.5 \mathrm{~mL})$ and $4 \%$ sodium carbonate solution $(2 \mathrm{~mL})$. After $2 \mathrm{~h}$ at $25 \pm 3{ }^{\circ} \mathrm{C}$, the absorbance was measured at $740 \mathrm{~nm}$. For the total flavonoids, $500 \mu \mathrm{L}$ of an ETE dilution (ETE:70\% ethanol solution, 1:10, $\mathrm{mL}: \mathrm{mL})$ was mixed with $80 \%$ ethanol solution $(4.3 \mathrm{~mL}), 10 \%$ aluminium nitrate $(100 \mu \mathrm{L})$ and $10 \%$ potassium acetate $(100 \mu \mathrm{L})$. The absorbance was measured at $415 \mathrm{~nm}$ after $40 \mathrm{~min}$ at $25 \pm 3{ }^{\circ} \mathrm{C}$. All readings were done at $20^{\circ} \mathrm{C}$. A gallic acid (GA) standard curve was used to express the total phenolic content in a mg of GA equivalents (GAE)/g of sample, and a quercetin (Q) standard curve was used to express the flavonoid content in $\mathrm{mg}$ of $\mathrm{Q}$ equivalents $(\mathrm{QE}) / \mathrm{g}$ of sample.

\subsection{Identification and quantification of phenolic compounds by HPLC-PDA}

The individual phenolic compounds of ETE were analysed as proposed by Rubilar, Pinelo, Shene, Sineiro, and Nuñez (2007) and adapted by De-Melo et al. (2018). The flow rate was $1 \mathrm{~mL} / \mathrm{min}$, and the mobile phase was composed of two solvents: water and methanol (both acidified with $0.1 \%$ formic acid). A gradient elution was adopted for $100 \mathrm{~min}$, after the injection of the ETE $(20 \mu \mathrm{L})$ into the HPLC system. Detection was done by scanning between 190 and $600 \mathrm{~nm}$, and quantification was carried out at 280,320 and $360 \mathrm{~nm}$ depending on the maximum absorption of the identified compound. Standard curves were constructed with different concentrations of phenolic compounds, assuming $100 \%$ purity, prepared in methanol, and the results were expressed as $\mathrm{mg}$ of compound/100 $\mathrm{g}$ of sample.

\subsection{Antioxidant capacity}

The antioxidant capacity of the ETE was determined using DPPH and oxygen radical absorbance capacity (ORAC) assays. These methods were used to evaluate the bioactive compounds in different systems (DPPH: non-competitive system; ORAC: competitive system) and against different radicals (DPPH•; ORAC: peroxyl generated from AAPH).

\subsection{1. $D P P H$}

The assay was done as described by Brand-Williams, Cuvelier, and Berset (1995), with the modifications proposed by De-Melo et al. (2016). The ETE ( $500 \mu \mathrm{L})$ reaction with $1.5 \mathrm{~mL}$ of a solution of DPPH in methanol (absorbance between 0.600 and 0.700 at $517 \mathrm{~nm}$ ) was measured, after $30 \mathrm{~min}$ at $25 \pm 3^{\circ} \mathrm{C}$, at $517 \mathrm{~nm}$ in an instrument operating at $20^{\circ} \mathrm{C}$. Different dilutions of each ETE were analysed to construct a standard curve of concentration ( $\mathrm{mg}$ of sample/mL of extract) vs. percentage discoloration (PD). The PD was determined based on the formula proposed by Mensor et al. (2001):

$\mathrm{PD}(\%)=\left\{1-\left[\mathrm{Abs}_{\text {sample }}-\mathrm{Abs}_{\mathrm{sc}} / \mathrm{Abs}_{\text {control }}\right]\right\} \times 100$,

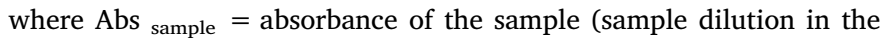
DPPH solution);Abs ${ }_{s c}=$ absorbance of the specific control (sample dilution in methanol);Abs control $=$ absorbance of the control (methanol in DPPH solution).

The standard curves constructed were required to express the results as $\mathrm{EC}_{50}$, i.e. the minimum concentration (mg of sample/mL of extract) to reduce $50 \%$ of the DPPH radical. The results were also expressed in $\mu$ mol of Trolox equivalents per $g$ of dehydrated bee pollen (TE/g), using a standard curve constructed with different concentrations of Trolox (ranging from 6.25 to $100 \mu \mathrm{mol} / \mathrm{L}$ ) in methanol.

\subsubsection{ORAC}

The antioxidant capacity of ETE was determined using the ORAC assay as described by Huang, Ou, and Prior (2005), considering the modifications proposed by De-Melo et al. (2016). The ETE $(25 \mu \mathrm{L})$ was reacted with $150 \mu \mathrm{L}$ of fluorescein $\left(4.0 \times 10^{10} \mathrm{M}\right.$, in $75 \mathrm{mM}$ sodium phosphate buffer pH 7.4) and $25 \mu \mathrm{L}$ of AAPH $(0.153 \mathrm{M}$, in $75 \mathrm{mM}$ sodium phosphate buffer $\mathrm{pH}$ 7.4) was measured, in the microplate reader at $37^{\circ} \mathrm{C}$, every $1 \mathrm{~min}$ for $1 \mathrm{~h}\left(\lambda_{\text {excitation }}: 485 \mathrm{~nm} ; \lambda_{\text {emission }}: 520 \mathrm{~nm}\right)$. Five different dilutions of each ETE in $75 \mathrm{mM}$ sodium phosphate buffer ( $\mathrm{pH}$ 7.4) were tested to confirm the results. A Trolox ${ }^{\star}$ standard curve was constructed, and the relative value of ORAC was calculated based on a linear regression equation between the concentration of Trolox ${ }^{\circ}$ and the area under the fluorescence curve automatically generated by the equipment. The results were expressed in TE/g.

\subsection{Antimicrobial capacity}

The antimicrobial capacity of MEE was tested against American Type Culture Collection (ATCC) strains (LGC Standards S.L.U., Barcelona, Spain): Escherichia coli $25922^{\mathrm{TM}}$, Klebsiella BAA1705 ${ }^{\mathrm{TM}}$, Streptococcus pyogenes $12344^{\mathrm{TM}}$, Staphylococcus aureus $25923^{\mathrm{TM}}$ and Candida albicans $60193^{\mathrm{TM}}$. The MEE were also tested against bacteria and yeasts isolated from biological fluids and identified in the Northeast Hospital Centre, Bragança, Portugal: E. coli ESA72 (urine), Klebsiella ESA61 (blood), S. pyogenes ESA12 (purulent exudate), S. aureus ESA54 (pus) and C. albicans ESA109 (saliva). The isolated microorganisms were stored in Müeller Hinton medium plus $20 \%$ glycerol (mL:mL) at $-70{ }^{\circ} \mathrm{C}$ in a freezer.

The microorganisms were prepared as described by De-Melo et al. 
(2016): bacteria were plated on nutrient broth $\left(37 \pm 1{ }^{\circ} \mathrm{C}\right.$ for $\left.24 \mathrm{~h}\right)$, and yeasts on yeast nitrogen base $\left(25 \pm 1{ }^{\circ} \mathrm{C}\right.$ for $\left.48 \mathrm{~h}\right)$. Inocula were obtained by diluting the cell mass in $0.85 \%$ sodium chloride solution, adjusted to 0.5 on the MacFarland scale, and confirmed with a spectrophotometer reading at $580 \mathrm{~nm}$ (bacteria) or $640 \mathrm{~nm}$ (yeasts). Finally, these cell suspensions were diluted to $10^{4} \mathrm{CFU} / \mathrm{mL}$. MEE were dissolved in DMSO to $50 \mathrm{mg} / \mathrm{mL}$. Tests were done as proposed by Morais et al. (2011), using nutrient broth and incubation for $24 \mathrm{~h}$ at $37 \pm 1{ }^{\circ} \mathrm{C}$ (bacteria), or yeast nitrogen base and incubation for $48 \mathrm{~h}$ at $25 \pm 1{ }^{\circ} \mathrm{C}$ (yeasts). Antimicrobial capacity was detected by adding $20 \mu \mathrm{L}$ of TTC solution. Fluconazole and gentamycin were used as positive controls, and the results were expressed as minimum inhibitory concentration (MIC), i.e. the lowest concentration of MEE that inhibited visible growth of strains.

\subsection{Statistical analysis}

Results were obtained from triplicate analysis and expressed as mean-pooled standard deviation. Before their means were compared, samples were formally tested for equality of variances using the BrownForsythe's test ( $\mathrm{n} \geq 3$ variances) or by the $F$-test ( $\mathrm{n}=2$ variances). Then, one-way ANOVA or Welch-ANOVA ( $\mathrm{n} \geq 3$ samples) followed by the Fisher's LSD test or Student's $t$-test for independent samples ( $\mathrm{n}=2$ groups) was used to highlight differences at $\mathrm{p} \leq 0.05$ (Granato, Calado, \& Jarvis, 2014). Statistica v.7 software (Statsoft, Tulsa, OK, USA) was used for the analysis.

The geographical and the botanical origin of bee pollen samples were studied using an exploratory multivariate approach, namely principal component analysis (PCA). For that purpose, the means were auto-scaled to unit variance, and PCA was based on a correlation analysis in which variances were calculated as the (sum of squares)/ $(n-1)$. Factor loadings higher than 0.45 were used to interpret the projection of samples on a two-dimensional plane (Zielinski et al., 2014). Hierarchical cluster analysis (HCA) based on the Ward's method and (1 - Pearson correlation coefficient) distances was also used to classify the pollen samples according to the following variables: contents of protein, iron, quercetin, total phenolic compounds, antioxidant activity measured by ORAC, and inhibition of $S$. aureus ESA 54. Four groups were formed and compared using Student's $t$-test (2 groups) or one-way ANOVA ( $\geq 3$ groups) followed by the Fisher's LSD test, when applicable. All statistical analyses were done using the Statistica v.7 software and Action 2.9 (Statcamp, São Carlos, SP, Brazil).

\section{Results and discussion}

\subsection{Botanical origin}

Thirty-eight pollen types were identified to species, genus or family levels, of which 28 were present in more than one sample from different states and regions of Brazil (Table 1). Monofloral pollen loads contain pollen grains from a unique plant species. When Apis mellifera L. bees visit more than one species during foraging to obtain a product that meets their nutritional needs, a heterofloral sample is produced (Barth et al., 2010; De-Melo \& Almeida-Muradian, 2017; Komosinska-Vassev et al., 2015). Of the 56 samples analysed, 20 were monofloral (36\%), i.e. they had a unique predominant pollen type (13 taxa). The other 36 samples (64\%) were classified as heterofloral, since there was no predominant pollen type, and two or more taxa constituted the sample's pollen spectrum.

A total of 19 monofloral samples were observed. Brassica was the most frequent taxon (4 samples) amongst the monofloral samples, originating from three states (Mato Grosso, Rio Grande do Sul and São Paulo). It includes the ruderal species $B$. rapa (field mustard). The following pollen types predominated in two monofloral samples each: Astrocaryum aculeatissimum (Bahia and São Paulo), Cocos nucifera (Bahia), Myrcia (Rio Grande do Sul and São Paulo) and Alternanthera (São Paulo). Each of the other taxa contributed to only one sample. In addition to the pollen that constituted the monofloral pollen samples, 10 more taxa were identified amongst the heterofloral samples making up more than $15 \%$ in each sample. The microscopic images of some pollen grains found in Brazilian bee pollen samples are shown in Fig. 1.

Plants considered ruderal, native or spontaneous (Lorenzi, 2000) were always more representative in the set of samples analysed. Cultivars visited less frequently by bees included C. nucifera, Eucalyptus and Coffea. The importance of ruderal areas, such as capoeiras, pastures and forest edges, has been shown for the healthy survival of the bees as well as, consequently, a notable honey and pollen production for general consumption.

\subsection{Physicochemical parameters and biological potential}

The chemical composition of each sample is shown in the Table 2. Protein levels ranged from 7.9 to $32.2 \mathrm{~g} / 100 \mathrm{~g}$. In $29 \%$ of the samples, this content was higher than in beans, lentils and meat, which contain approximately 20,23 and $24 \mathrm{~g}$ of protein $/ 100 \mathrm{~g}$, respectively (University of Campinas, 2006). The lipid content varied from 3.2 to $13.5 \mathrm{~g} / 100 \mathrm{~g}$, and the ash content was between 1.9 and $3.6 \mathrm{~g} / 100 \mathrm{~g}$. Based on the calculation of the difference, the carbohydrate levels by difference ranged from 54.9 to $82.8 \mathrm{~g} / 100 \mathrm{~g}$. These results corroborate the variations described by Bogdanov (2012), De-Melo and AlmeidaMuradian (2017) as well as Nogueira, Iglesias, Feás, and Estevinho (2012) for bee pollen samples: $2.5-62 \mathrm{~g} / 100 \mathrm{~g}$ of proteins, $0.2-22 \mathrm{~g} /$ $100 \mathrm{~g}$ of lipids and $0.5-6 / 100 \mathrm{~g}$ of ash.

Some researchers have already suggested that bee pollen composition can vary depending on its geographical and botanical origins (Bogdanov, 2012; Campos et al., 2008; Carpes et al., 2008; De-Melo et al., 2018; Yang et al., 2013); which could explain the difference in composition of the samples analysed in the present study. According to De-Melo and Almeida-Murdian (2017), climatic conditions, soil characteristics as well as age and nutritional state of the plant influence the development and composition of the pollen grains and, consequently, the bee pollen composition produced from these grains. Additionally, collection and processing practices adopted by beekeepers could also influence ash content, as contamination by soil or other inorganic residues can occur (Morgano et al., 2010).

$\mathrm{Fe}, \mathrm{Cu}, \mathrm{Ca}, \mathrm{Mg}, \mathrm{Zn}, \mathrm{Mn}, \mathrm{Na}$ and $\mathrm{K}$ levels are described in Table 2 for each sample. $\mathrm{K}$ was found in higher quantities $(3.4-9.8 \mathrm{~g} / \mathrm{kg}$ ), followed by $\mathrm{Ca}(0.9-4.1 \mathrm{~g} / \mathrm{kg}), \mathrm{Mg}(0.6-2.4 \mathrm{~g} / \mathrm{kg}), \mathrm{Fe}(46-1180 \mathrm{mg} / \mathrm{kg}), \mathrm{Na}$ $(20-374 \mathrm{mg} / \mathrm{kg}), \mathrm{Mn}(25-215 \mathrm{mg} / \mathrm{kg}), \mathrm{Zn}(30-101 \mathrm{mg} / \mathrm{kg})$ and $\mathrm{Cu}$ $(7.4-19.7 \mathrm{mg} / \mathrm{kg})$. Other researchers have also identified variations in $\mathrm{K} \quad(1.4-38 \mathrm{~g} / \mathrm{kg}), \quad \mathrm{Ca} \quad(0.2-5.8 \mathrm{~g} / \mathrm{kg}), \quad \mathrm{Mg} \quad(0.2-4.7 \mathrm{~g} / \mathrm{kg}), \quad \mathrm{Fe}$ (11.1-1290 mg/kg), Na (< 0.004-1470 mg/kg), Mn (5-430 mg/kg), Zn $(5.1-340 \mathrm{mg} / \mathrm{kg}$ ) and $\mathrm{Cu}(3-42 \mathrm{mg} / \mathrm{kg}$ ) contents (De-Melo \& AlmeidaMuradian, 2017) and, consequently, the values of the present study are within the expected ranges for this food. The mineral content of bee pollen can vary according to botanical and geographical origins, and soil composition (Yang et al., 2013).

Considering the Recommended Dietary Allowance (RDA) of the Institute of Medicine of the USA (1997, 2001, 2005, 2011) for males (31-50 years old), for instance, a $25 \mathrm{~g}$ portion (an equivalent of one 


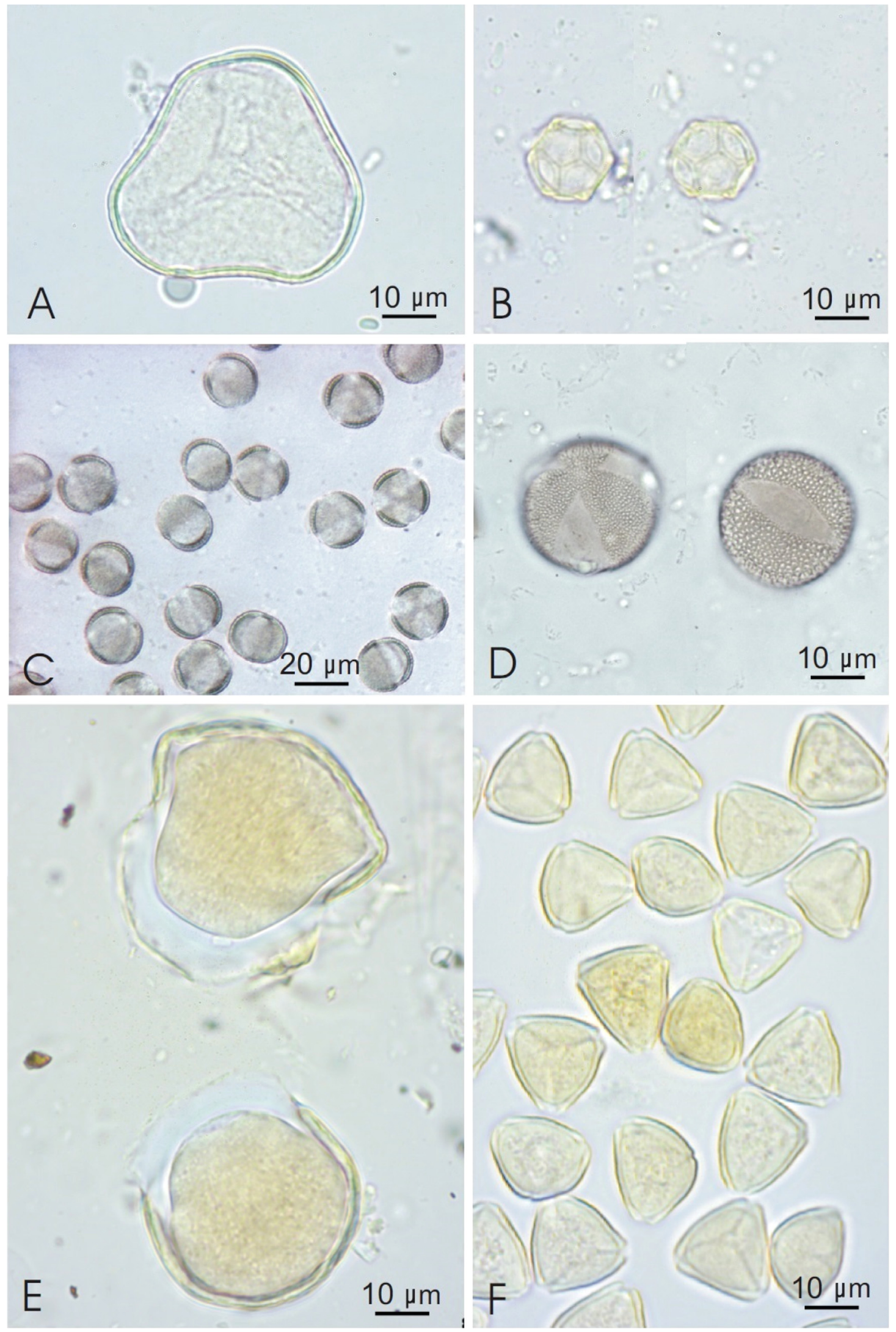

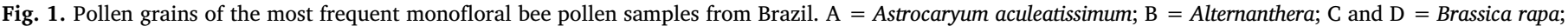
$\mathrm{E}=$ Cocos nucifera. $\mathrm{F}=$ Myrcia. 
soup spoon) of the bee pollen samples could provide up to the following: $100 \%$ of the RDA for $\mathrm{Cu}, \mathrm{Mn}$ and $\mathrm{Fe} ; 77 \%$ of the RDA for $\mathrm{Zn}$; $28 \%$ of the RDA for $\mathrm{Mg} ; 15 \%$ of the RDA for $\mathrm{Ca}$; and less significant amounts (5\%) of the RDA for K. The elevated content of certain compounds in these samples is a highly relevant finding since it suggests that the consumption of this food would be an alternative for avoiding mineral deficiencies. Besides, it is important to consider that the $\mathrm{Na}$ content in this $25 \mathrm{~g}$ portion corresponds to only $2-5 \%$ of the maximum intake of $2 \mathrm{~g}$ /day recommended by the World Health Organization (2012).

Total phenolic (TP) and total flavonoid (TF) values in the ETE of the 56 Brazilian bee pollen samples are shown in Table 3 . The values observed (TP: $6.5-29.2 \mathrm{mg}$ GAE/g; TF: $0.3-17.5 \mathrm{mg}$ QE/g) were below those found by Carpes et al. (2008) in samples from Southern Brazil (TP: $19.3-49 \mathrm{mg} \mathrm{GAE} / \mathrm{g}$; TF: $2.1-28.3 \mathrm{mg} \mathrm{QE} / \mathrm{g}$ ). By contrast, as reviewed by De-Melo and Almeida-Murandian (2017), the TP content in bee pollen can vary from 0.5 to $213 \mathrm{mg} \mathrm{GAE} / \mathrm{g}$. These parameters vary depending on the botanical origin of the bee pollen (Campos et al., 2008; De-Melo et al., 2018; Morais et al., 2011); however, variations are also observed depending on the dehydration conditions used by beekeepers (De-Melo et al., 2016).

All compounds quantified by HPLC-PDA represented from $0.5 \%$ to $42 \%$ of the TP, whereas only the flavonoids represented from $0.3 \%$ to $26 \%$ of the TP. Chromatographic behaviours of the peaks also indicated a higher occurrence of flavonoids in comparison with other phenolic compounds, such as phenolic acids, given that most of the peaks occurred between 30 and $40 \mathrm{~min}$, and mainly after $50 \mathrm{~min}$, when the mobile phase favoured the elution of lower-polarity compounds. According to the gradient used, the higher the polarity of the compound is, the quicker its elution is, and it is known that phenolic acids have a high polarity, whereas the flavonoids have a comparatively lower polarity.

The contents of phenolic compounds derived from benzoic and cinnamic acids as well as the flavonoid levels in each dehydrated bee pollen are shown in Table 3. There was variation in the flavonoid content [rutin (3-237 mg/100 g), naringenin (1-143 mg/100 g), kaempferol (1.3-101 mg/100 g), quercetin (1.5-63 mg/100 g), catechin $(0.7-20 \mathrm{mg} / 100 \mathrm{~g})$, naringin $(0.4-10 \mathrm{mg} / 100 \mathrm{~g})$ and epicatechin $(0.4-2.9 \mathrm{mg} / 100 \mathrm{~g})]$ and in the content of phenolic compounds derived from benzoic and cinnamic acids [ $\beta$-resorcylic acid $(2.7-381 \mathrm{mg}$ / $100 \mathrm{~g})$, cinnamic acid $(0.7-21.1 \mathrm{mg} / 100 \mathrm{~g})$, ferulic acid $(0.7-19$ $\mathrm{mg} / 100 \mathrm{~g})$, syringic acid $(0.9-14.8 \mathrm{mg} / 100 \mathrm{~g}), \quad p$-coumaric acid $(0.3-11.5 \mathrm{mg} / 100 \mathrm{~g})$, chlorogenic acid $(1.3-8.9 \mathrm{mg} / 100 \mathrm{~g})$, vanillic acid $(0.6-7.8 \mathrm{mg} / 100 \mathrm{~g})$, caffeic acid $(0.8-5.2 \mathrm{mg} / 100 \mathrm{~g})$, protocatechic acid $(1.1-3.1 \mathrm{mg} / 100 \mathrm{~g})$, gallic acid $(1.5-2.1 \mathrm{mg} / 100 \mathrm{~g})$ and synapic acid $(0.1-0.2 \mathrm{mg} / 100 \mathrm{~g})]$ between the samples investigated. Rutin was the most common compound, being identified in $68 \%$ of the samples, and gallic acid was the least common compound, being identified in $3.5 \%$ of the samples.

When analysing bee pollen produced in Turkey, Ulusoy and Kolayli (2014) identified gallic, protocatechic, chlorogenic, vanillic, caffeic, syringic, $p$-coumaric, ferulic and trans-cinnamic acids in amounts varying from 4.7 to $259 \mu \mathrm{g} / 100 \mathrm{~g}$; in addition to the flavonoids epicatechin, rutin and quercetin, whose levels varied from 25.6 to $693 \mu \mathrm{g}$ / $100 \mathrm{~g}$. These values were below those observed in the present study. DeMelo et al. (2018) found $1.5 \mathrm{mg} / 100 \mathrm{~g}$ of protocatechic acid, $0.5-6.7 \mathrm{mg} / 100 \mathrm{~g}$ of $p$-coumaric acid, $13.1 \mathrm{mg} / 100 \mathrm{~g}$ of cinnamic acid, $3.7-46.8 \mathrm{mg} / 100 \mathrm{~g}$ of rutin and $1.9-67.9 \mathrm{mg} / 100 \mathrm{~g}$ of quercetin in bee pollen from Brazil; and these values are within the ranges observed in the present study.

Certain phenolic compounds could serve as markers for determining the botanical origin of bee pollen (Ulusoy \& Kolayli, 2014); this is something that, according to Kaskoniené and Venskutonis (2010), has already been done with honey. The hypothesis that each plant species produced a specific phenolic compound profile in quantitative and qualitative terms has been studied for a few years. Campos et al. (2015), 


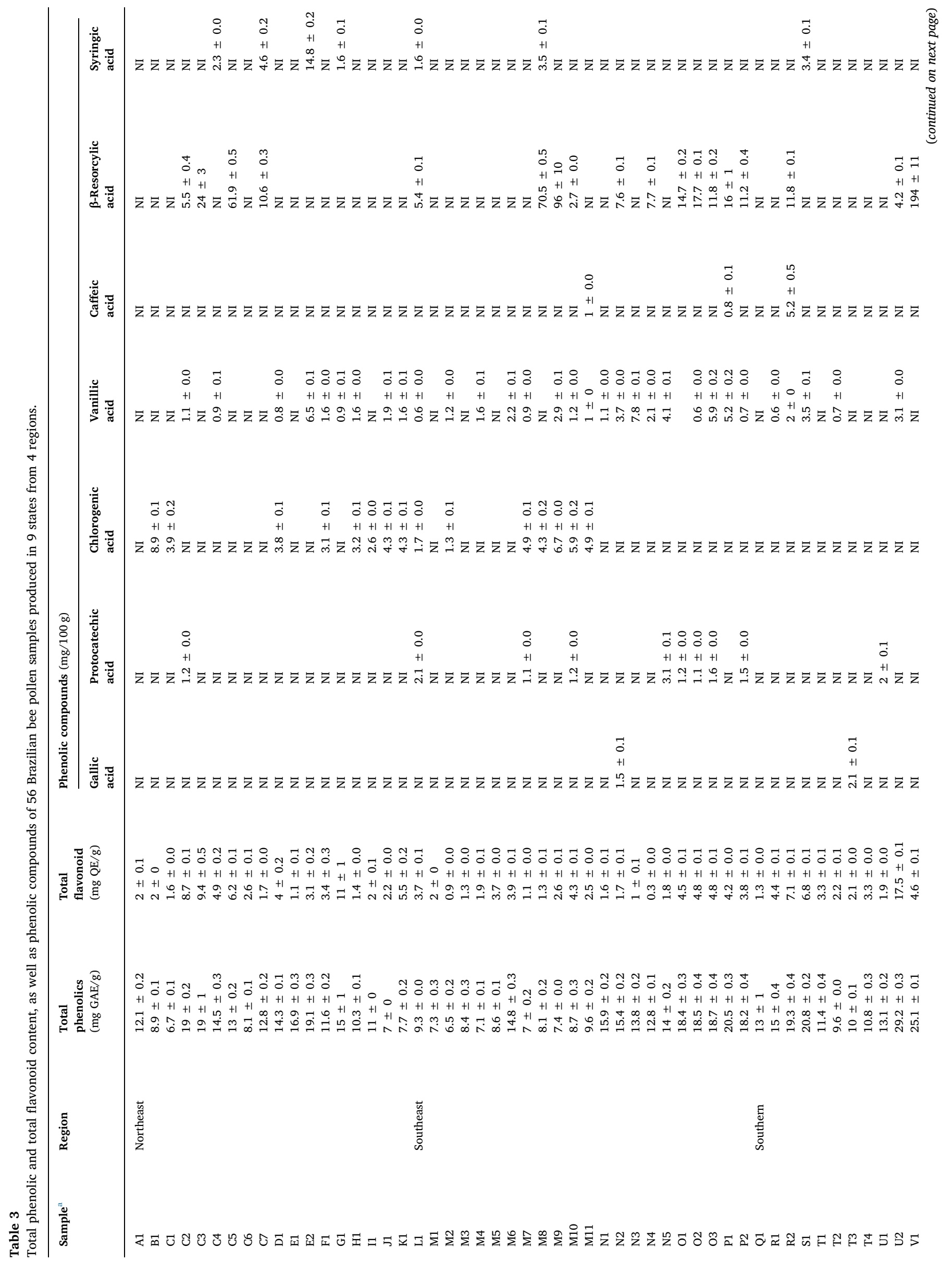




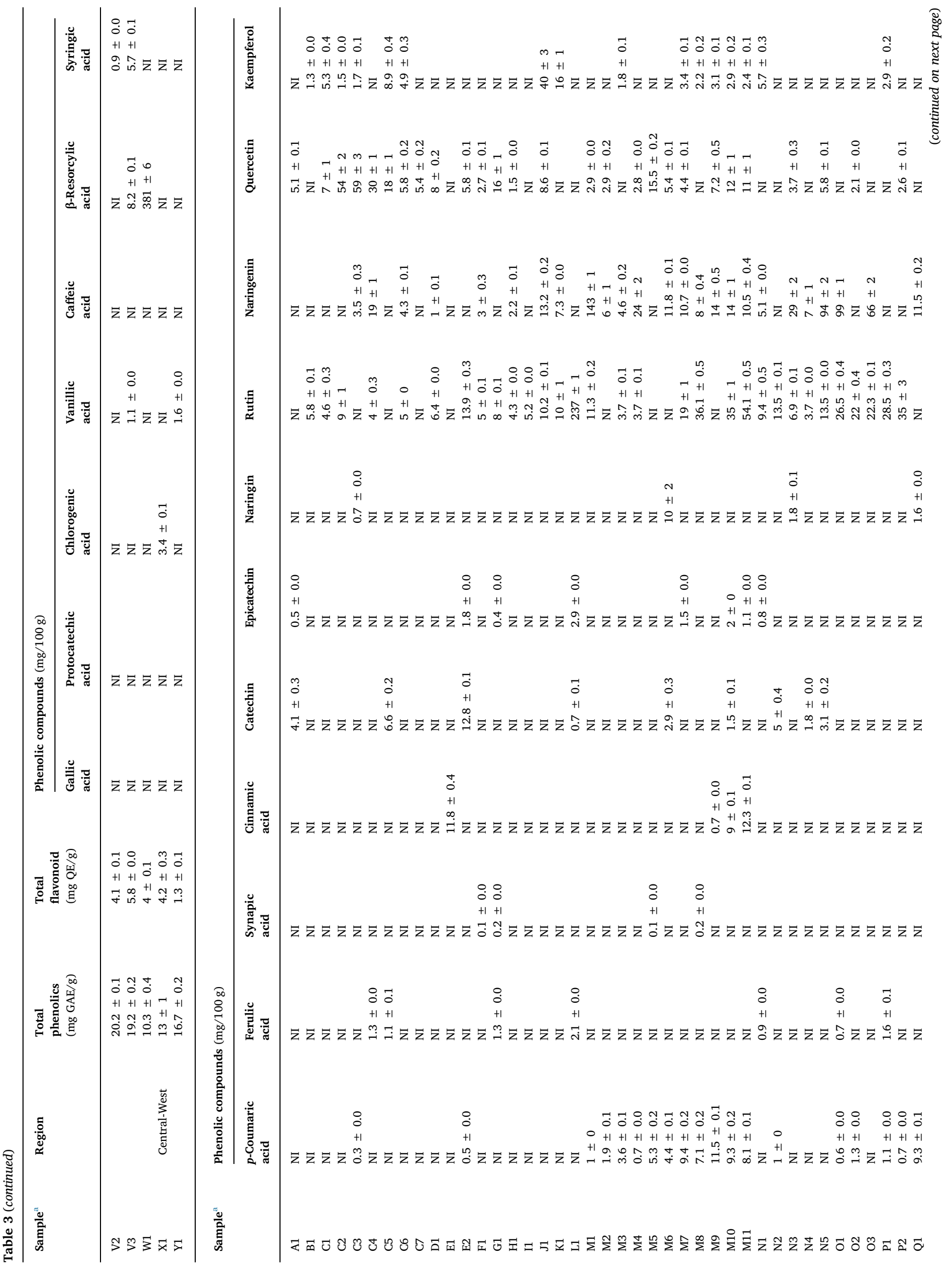




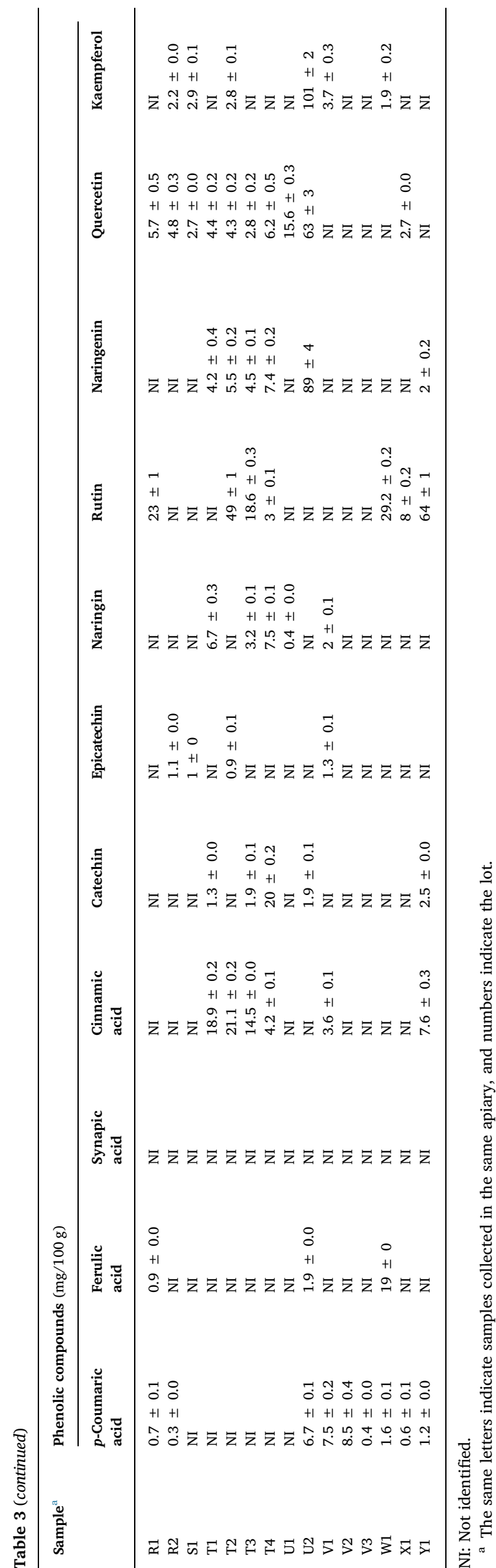

when analysing Zea mays monofloral bee pollen from Portugal, Brazil and Mexico, observed that the profiles did not vary during the sampling period (2000-2012) or according to geographic origin. The same did not occur with Mimosa scabrella monofloral bee pollen analysed by DeMelo et al. (2018), since the authors observed different phenolic profiles according to the Brazilian region from which the samples were collected. They attributed the variation to agronomic or genotypic differences between the plants as well as climatic and soil conditions that could influence the pollen composition of Mimosa scabrella. In the present study, the phenolic compound profiles of the $C$. nucifera monofloral bee pollen were similar in quantitative and qualitative terms; however, more samples should be studied to suggest that this bee pollen type could have a species-specific profile.

Phenolic compounds have been considered bioactive substances, and a positive correlation between the phenolic content, especially flavonoids, and the antioxidant capacity of bee pollen has already been reported (Leblanc, Davis, Boue, Delucca, \& Deeby, 2009; Mohdaly, Mahmoud, Roby, Smetanska, \& Ramadan, 2015). Based on Pearson's correlation, there was some correlation between antioxidant capacity and total phenolic content (DPPH: $r=0.57$ and $\mathrm{p}=0.00$; ORAC: $\mathrm{r}=0.61$ and $\mathrm{p}=0.00$ ), and between flavonoid content and antioxidant capacity (DPPH: $\mathrm{r}=0.46$ and $\mathrm{p}=0.00 ;$ ORAC: $\mathrm{r}=0.64$ and $\mathrm{p}=0.00$ ). From the phenolic compounds identified using HPLC-PAD, only quercetin seems to have positively influenced the antioxidant capacity of bee pollen, since there was a correlation with the values found in both methods (DPPH: $\mathrm{r}=0.49$ and $\mathrm{p}=0.00 ;$ ORAC: $\mathrm{r}=0.66$ and $\mathrm{p}=0.00$ ). Quercetin has $5-\mathrm{OH}$ groups, including a $3-\mathrm{OH}$ group on the $\mathrm{C}$ ring conjugated through a 2,3-double bond to the $3^{\prime}, 4^{\prime}$-catechol structure of the $\mathrm{B}$ ring, which confers a greater capacity to deactivate reactive species (Heim et al., 2002), such as the radical peroxyl used in the ORAC method. Therefore, the structure could explain the correlation observed between the quercetin and the antioxidant capacity of the samples.

All the results for antioxidant capacity, using the ORAC and DPPH methods, of the analysed bee pollen samples are shown in Table 4. The results varied according to the sample and the methodology of the analysis used. When the DPPH method was used, the values varied between 9.4 and $155 \mu \mathrm{mol} \mathrm{TE} / \mathrm{g}\left(\mathrm{EC}_{50}\right.$ : 0.4-7.9), whereas when the ORAC method was used, the variation was from 133 to $563 \mu \mathrm{mol} \mathrm{TE} / \mathrm{g}$. These discrepancies could be related to the different reactive species (DPPH: DPPH - ORAC: radical peroxyl) or the different reaction schemes (DPPH: non-competitive; ORAC: competitive). In addition, each antioxidant has an intrinsic capacity to or not to deactivate the reactive species, as discussed above. The average antioxidant capacity of the bee pollen samples by the ORAC assay $(273 \mu \mathrm{mol} \mathrm{TE} / \mathrm{g})$ was higher than that reported in the literature for some fruits, such as strawberries (43 $\mu \mathrm{mol} \mathrm{TE} / \mathrm{g}$ ), raspberries (192 $\mu \mathrm{mol} \mathrm{TE} / \mathrm{g}$ ), blueberries (96 $\mu \mathrm{mol} \mathrm{TE} / \mathrm{g}$ ) and cranberries $(91 \mu \mathrm{mol} \mathrm{TE} / \mathrm{g}$ ) (United States Department of Agriculture, 2010).

The antimicrobial capacity of the 56 samples is given in Table 4. All the extracts inhibit the growth of the microorganisms tested; however, the MIC varied according to the sample and the microorganism investigated. Gram-positive bacteria were more sensitive than Gram-negative bacteria. The MIC for $S$. pyogenes strains ranged from 1.1 to $6.5 \mathrm{mg} / \mathrm{mL}$ and that for $S$. aureus strains varied from 1.6 to $7.2 \mathrm{mg} / \mathrm{mL}$; MIC from 1.9 to $8.1 \mathrm{mg} / \mathrm{mL}$ and from 2.4 to $9.2 \mathrm{mg} / \mathrm{mL}$ were required to inhibit the growth of the strains of E. coli and Klebisiella spp., respectively. Yeasts were more resistant than bacteria, with MIC varying between 7 and $29 \mathrm{mg} / \mathrm{mL}$ for C. albicans strains. Pascoal, Rodrigues, Teixeira, Féas, and Estevinho (2014), who also tested MEE of bee pollen samples, observed MIC values between 1.8 and $4.8 \mathrm{mg} / \mathrm{mL}$ for $S$. aureus, between 3.7 and $7 \mathrm{mg} / \mathrm{mL}$ for Pseudomonas aeruginosa, between 4.1 and $9.4 \mathrm{mg} / \mathrm{mL}$ for $E$. coli, and between 16 and $34 \mathrm{mg} / \mathrm{mL}$ for Candida glabrata.

There were no relevant correlations between antimicrobial capacity and total phenolic levels as well as between antimicrobial capacity and 


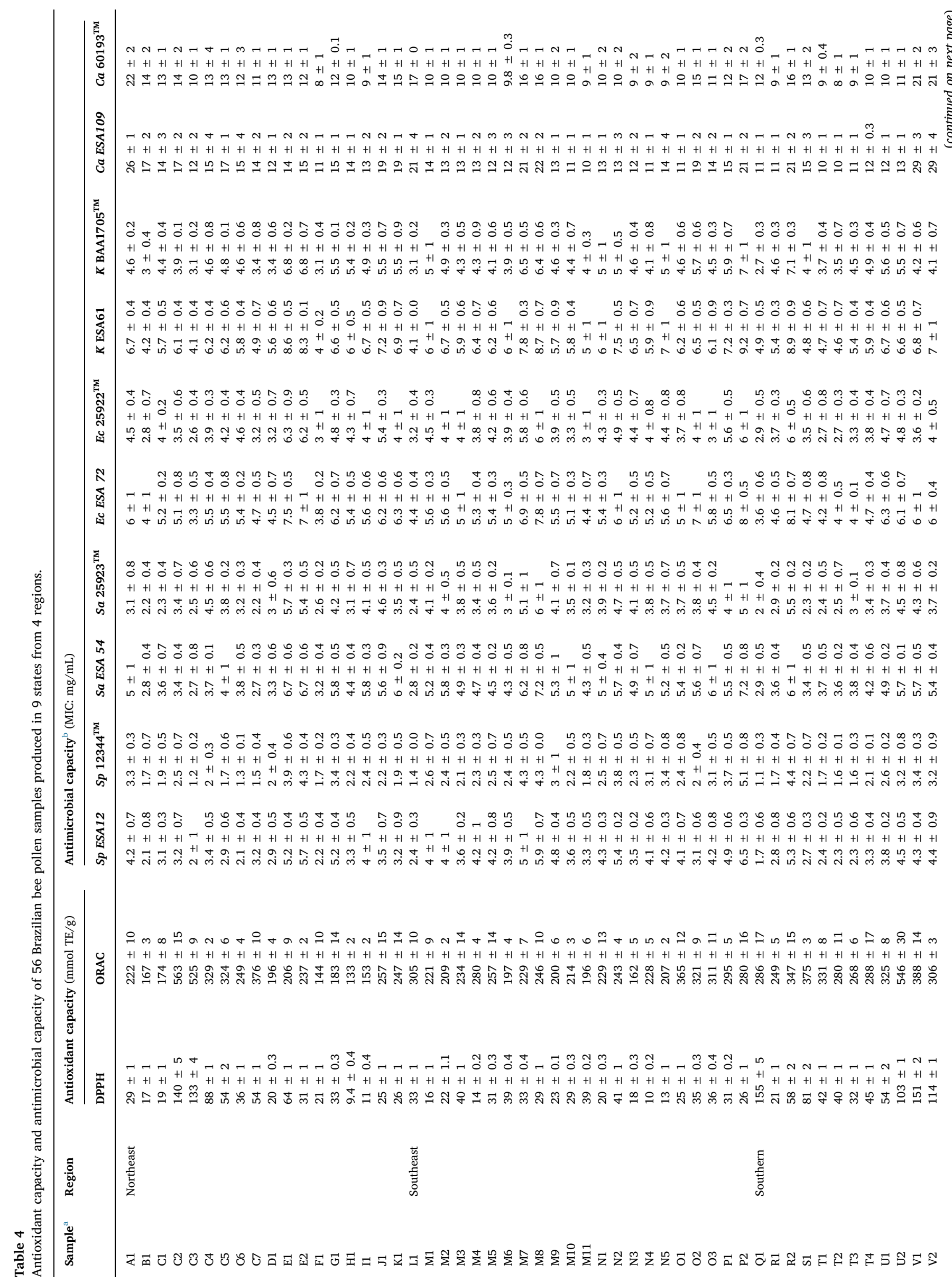

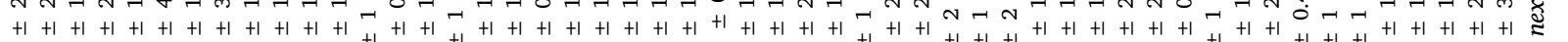

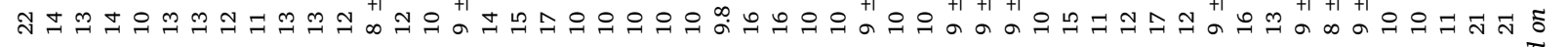

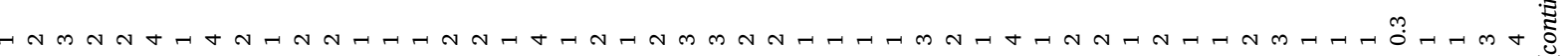

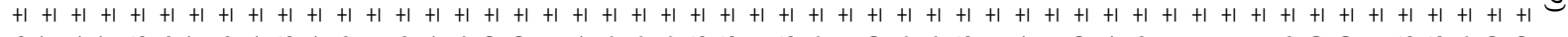

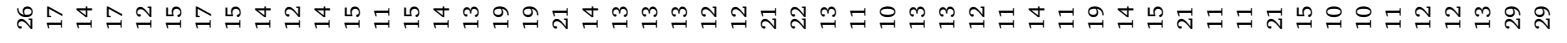

సี $+100+1+1+1+1+1+1+1+1+1+1+1+1+1+1+1+1+1-1+1+1+1+1+1+1+1+1+100-00+1+1-1+1+1+1+1-1+1+1+1-1+1+1+1+1+1+1+1+1$ 我 字

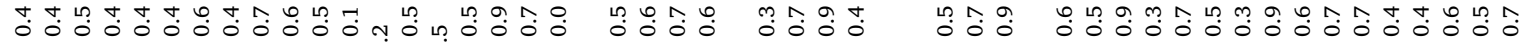
$+1+1+1+1+1+1+1+1+1+1+10+10+1+1+1+1-1+1+1+1+1-1+1+1+1+1-7-1+1+1+1-1+1+1+1+1+1+1+1+1+1+1+1+1+1+1+1+1-1$

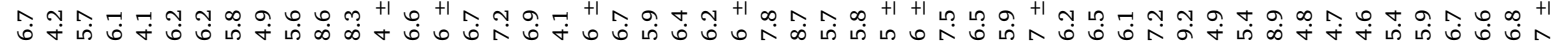

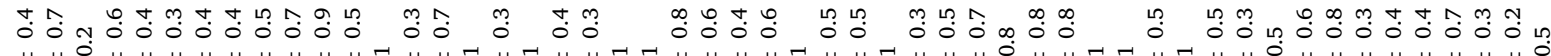

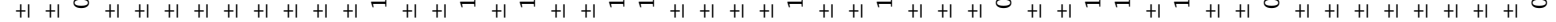

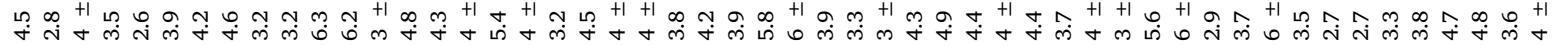

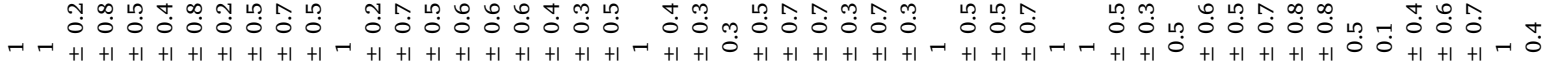

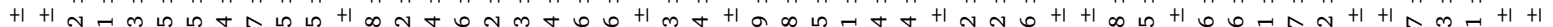
○

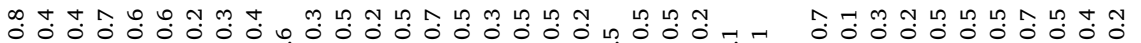

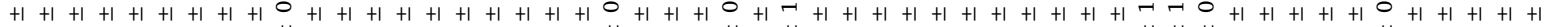

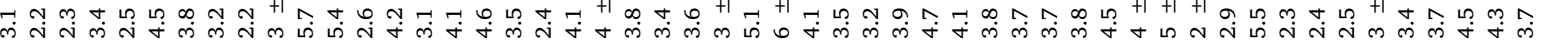

苛㑒范品

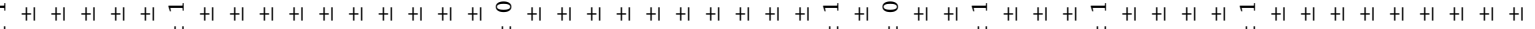

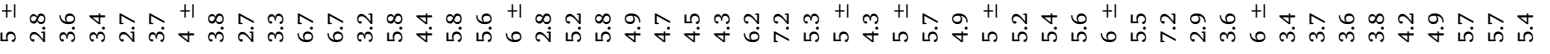

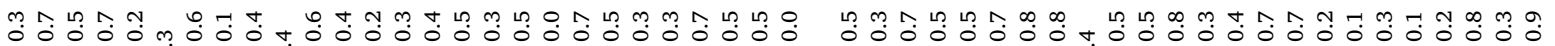
$+1+1+1+1+10+1+1+100+1+1+1+1+1+1+1+1+1+1+1+1+1+1+1+1+1-1+1+1+1+1+1+1+1+100+1+1+1+1+1+1+1+1+1+1+1+1+1+1+1$

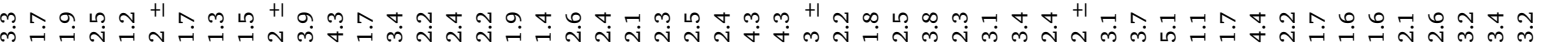

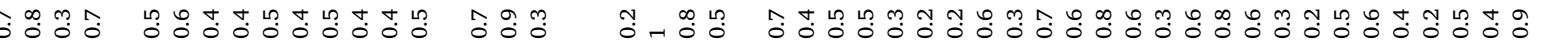

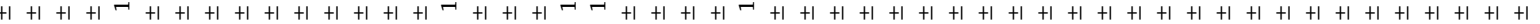

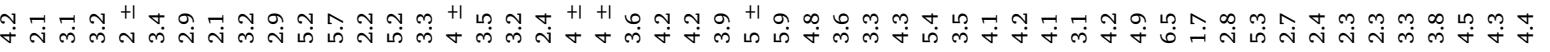


compounds identified and quantified by HPLC-PAD (all correlation values are available in Supplementary Table 1). It is possible that compounds different from those determined by HPLC-PDA are responsible for inhibition of the microorganisms tested. As it has already been observed in other studies (Campos et al., 2008; Carpes et al., 2008; Pascoal et al., 2014), the antimicrobial capacity of bee pollen seems to be related not to all but to specific compounds.

The determination of the instrumental colour parameters (Table 2) indicated variations in coordinates $L^{*}(48-72)$, $a^{*}(1-16.9)$ and $b^{*}(32-63)$ as well as $C(32-64)$. The colour of the bee pollen can vary according to its botanical origin, although pollen grains from the same species can have different colours, or different species can produce pollen grains with the same colour (Modro, Silva, Luz, \& Message, 2009; Vit \& Santiago, 2008). Additionally, the chemical composition can also influence the instrumental colour parameters of the bee pollen. There were correlations between these parameters and Ca levels and between $\mathrm{L}^{*}$ and $\mathrm{Mg}$ as well as Fe values (correlation values are shown in Supplementary Table 1). Consequently, the values of $\mathrm{L}^{*}, \mathrm{a}^{*}, \mathrm{~b}^{*}$ and $\mathrm{C}$ could be used to suggest the amount of these minerals in Brazilian bee pollen, with the advantage that the determination of these parameters involves a simple and rapid analysis without loss of samples. De-Melo et al. (2016) also evaluated Brazilian bee pollen samples and observed some correlation between instrumental colour parameters and total phenolic values, antioxidant capacity as well as antimicrobial capacity against certain microorganisms. In the present study, correlations between $L^{*}, b^{*}$ and $C$ values and total phenolic content, and correlation between $b^{*}$ and $C$ values and antioxidant capacity were observed (for the values, consult Supplementary Table 1).

\subsection{The exploratory multivariate approach using various parameters}

To identify patterns in the data, similarities and differences, the samples were grouped and analysed in consideration of the Brazilian region in which they were collected (SE: Southeast, SU: Southern, NE: Northeast), their classification as monofloral (M) or heterofloral $(\mathrm{H})$, and the pollen types, in addition to them being classified based on some physicochemical and biological properties. Samples from the CentralWest were not included in some of the analyses $(n=2)$.

Applying the PCA, the behaviour of the samples and groups was evaluated based on the correlation analysis. Three main components explained $68 \%$ of variance in the data set; however, the principal components 1 and 2 explained $54 \%$ of total variation. Thus, the twodimensional plots were created and discussed. PCA scores and loading plots of the two principal components are illustrated in Fig. 2 (the factor loadings are shown in Supplementary Table 2).

Principal component 1 (30\%) distinguished the samples in terms of total phenolic content and antimicrobial capacity against $S$. pyogenes ESA12, S. pyogenes $12344^{\mathrm{Tm}}, S$. aureus ESA54, S. aureus $25923^{\mathrm{TM}}$, E. coli ESA72, E. coli $25922^{\mathrm{Tm}}$, Klebsiella spp, Klebsiella BAA1705 ${ }^{\mathrm{TM}}$, and C. albicans ESA109. On the $x$-axis, the further to the left the projection of the sample, the higher the total phenolic content and the less the inhibition of the microorganisms are (negative principal component; however, the definition of MIC should be considered). Considering principal component 2 (24\%), the samples with the highest values of ash, Ca, Mg, L* and chlorogenic acid are in the upper quadrants, whereas the samples with higher total phenolic, antioxidant capacity (DPHH and ORAC), a*, $\mathrm{b}^{*}$ and $\mathrm{C}$ values are in the lower quadrants. The total phenolic content is correlated both on the $x$ - and $y$-axes; therefore, the lower and further to the left the projection of the sample, the higher the total phenolic content of the sample.

The proximity between the samples on the two-dimensional plot indicates similarities, and the opposite indicates differences. Samples from SU are distributed in the lower quadrants (Fig. 2A), indicating a tendency toward higher values for total phenolic and antioxidant capacity as well as lower ash, $\mathrm{Ca}, \mathrm{Mg}$, chlorogenic acid and $\mathrm{L}^{*}$ values in the bee pollen from this region. Samples from NE are mainly distributed 


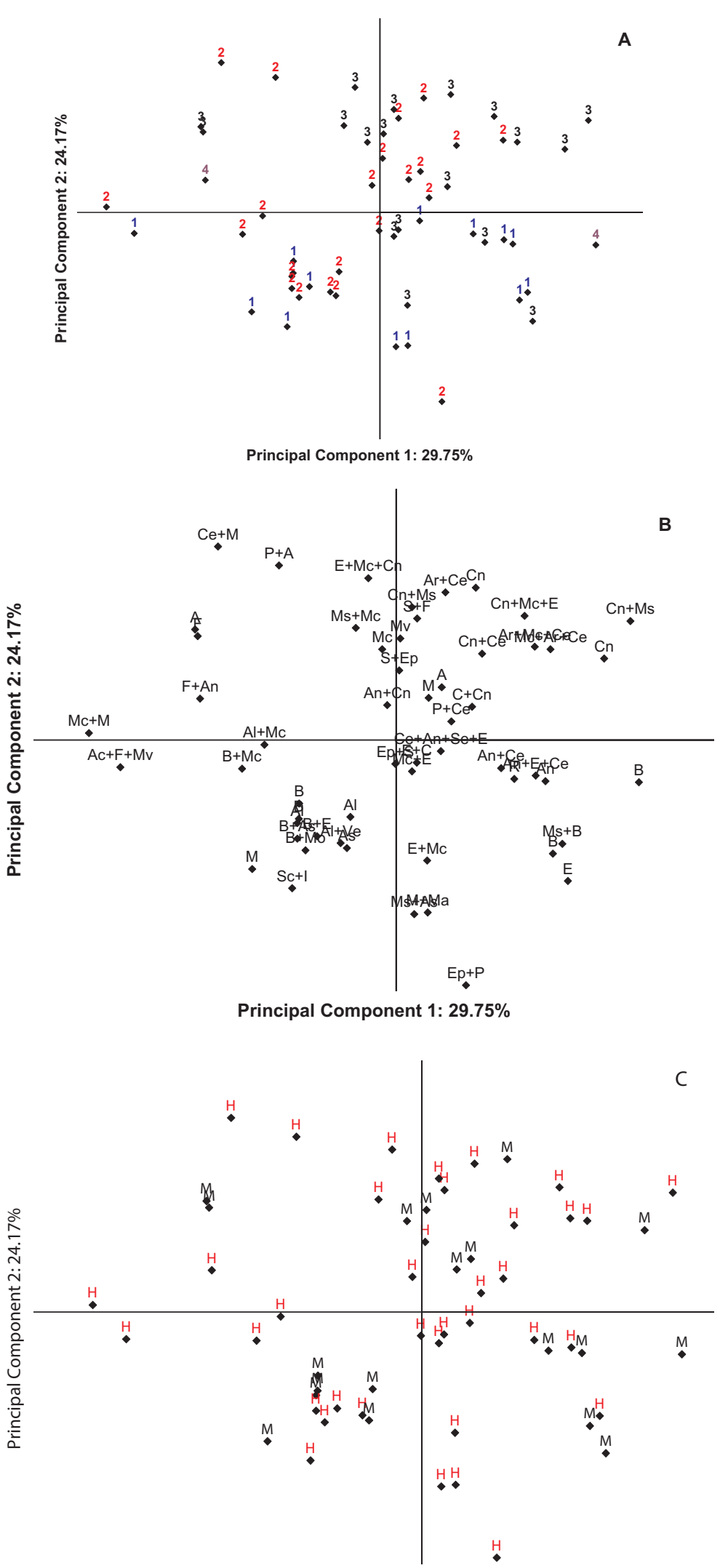

Principal Component 1: $29.75 \%$
Fig. 2. Projection of Brazilian bee pollen samples $(n=56)$ according to the geographical origin (A), pollen types (B), and classification based on the botanical origin (C). (1 A) = $1=$ Southern; 2 = Southeast; 3 = Northeast; 4 = Central-West. (1B) $=\mathrm{A}=$ Astrocaryum aculeatissimum; $\mathrm{Ac}=$ Anacardiaceae; $\mathrm{Al}=$ Alternanthera; $\mathrm{An}=$ Anadenanthera; $\mathrm{Ar}$ = Arecaceae; As = Asteraceae; $\mathrm{B}=$ Brassica; $\mathrm{C}=$ Coffea; Ce = Cecropia $; \mathrm{Cn}=$ Cocos nucifera $; \mathrm{E}=$ Eucalyptus; $\mathrm{Ep}=$ Eupatorium; $\mathrm{F}$ = Fabaceae; $\mathrm{I}=$ Ilex $; \mathrm{M}=$ Myrcia $; \mathrm{Ma}=$ Machaerium $; \mathrm{Mc}=$ Mimosa caesalpiniaefolia; Mo = Montanoa Ms = Mimosa scabrella; $\mathrm{Mv}=$ Mimosa verrucosa $; \mathrm{P}=$ Piper $; \mathrm{R}=$ Rubiaceae; $\mathrm{S}=$ Syagrus $; \mathrm{Sc}=$ Schinus $; \mathrm{Se}$

= Sebastiania; $\mathrm{Ve}=$ Vernonia $(1 \mathrm{C})=\mathrm{H}=$ Heterofloral; $\mathrm{M}$

= Monofloral. 
Table 5

Statistical comparison between distinct geographical origins of Brazilian pollen samples.

\begin{tabular}{|c|c|c|c|c|c|c|}
\hline Response variable & Northeast $(n=18)$ & Southern $(n=14)$ & Southeast $(n=22)$ & $\mathrm{PSD}^{\mathrm{a}}$ & P-value ${ }^{b}$ & P-value ${ }^{c}$ \\
\hline Proteins & $14.5^{\mathrm{b}}$ & $19.2^{\mathrm{a}}$ & $13.3^{\mathrm{b}}$ & 6.19 & 0.315 & 0.014 \\
\hline Lipids & $5.9^{c}$ & $8.5^{\mathrm{a}}$ & $7^{\mathrm{b}}$ & 1.93 & 0.001 & $<0.001$ \\
\hline Ashes & $3.1^{\mathrm{a}}$ & $2.8^{\mathrm{ab}}$ & $2.8^{\mathrm{b}}$ & 0.37 & 0.477 & 0.048 \\
\hline $\mathrm{Ca}$ & $2.7^{\mathrm{a}}$ & $1.7^{\mathrm{b}}$ & $2.1^{\mathrm{b}}$ & 0.75 & 0.044 & 0.001 \\
\hline $\mathrm{K}$ & $7.3^{\mathrm{a}}$ & $6.3^{\mathrm{b}}$ & $6.2^{\mathrm{b}}$ & 1.17 & 0.527 & 0.005 \\
\hline $\mathrm{Mg}$ & 1.7 & 1.5 & 1.4 & 0.39 & 0.066 & 0.069 \\
\hline $\mathrm{Na}$ & $118^{\mathrm{a}}$ & $52.6^{\mathrm{b}}$ & $55.4^{\mathrm{b}}$ & 62.1 & $<0.001$ & 0.001 \\
\hline $\mathrm{Zn}$ & $76.9^{\mathrm{a}}$ & $69.7^{\mathrm{ab}}$ & $63.8^{\mathrm{b}}$ & 16.1 & 0.013 & 0.034 \\
\hline $\mathrm{Fe}$ & $85.2^{\mathrm{b}}$ & $155^{\mathrm{ab}}$ & $263^{\mathrm{a}}$ & 208 & 0.02 & 0.021 \\
\hline Mn & $75.3^{\mathrm{b}}$ & $79.8^{\mathrm{b}}$ & $121^{\mathrm{a}}$ & 61.7 & $<0.001$ & 0.034 \\
\hline $\mathrm{Cu}$ & 13.4 & 14.2 & 13.6 & 2.96 & 0.779 & 0.746 \\
\hline$L^{*}$ & $68.5^{\mathrm{a}}$ & $61.7^{\mathrm{b}}$ & $62^{\mathrm{b}}$ & 6.61 & $<0.001$ & 0.001 \\
\hline$a^{*}$ & $2.5^{\mathrm{b}}$ & $7^{\mathrm{a}}$ & $6.1^{\mathrm{a}}$ & 3.65 & 0.002 & $<0.001$ \\
\hline$b^{*}$ & $37.4^{c}$ & $52.1^{\mathrm{a}}$ & $43.5^{\mathrm{b}}$ & 8 & 0.014 & $<0.001$ \\
\hline Chroma & $37.5^{c}$ & $52.6^{\mathrm{a}}$ & $44^{\mathrm{b}}$ & 8.33 & 0.007 & $<0.001$ \\
\hline Streptococcus pyogenes ESA12 & $3.4^{\mathrm{b}}$ & $3.3^{\mathrm{b}}$ & $4.2^{\mathrm{a}}$ & 1.09 & 0.412 & 0.02 \\
\hline S. pyogenes $12344^{\mathrm{TM}}$ & 2.3 & 2.4 & 2.8 & 0.93 & 0.843 & 0.128 \\
\hline Staphylococcus aureus ESA 54 & $4.4^{\mathrm{b}}$ & $4.4^{\mathrm{b}}$ & $5.2^{\mathrm{a}}$ & 1.2 & 0.095 & 0.041 \\
\hline S. aureus $25923^{\text {тм }}$ & $3.5^{\mathrm{ab}}$ & $3.2^{\mathrm{b}}$ & $4^{\mathrm{a}}$ & 0.98 & 0.282 & 0.05 \\
\hline Escherichia coli ESA 72 & 5.4 & 5.1 & 5.7 & 1.11 & 0.408 & 0.286 \\
\hline E. coli $25922^{\mathrm{TM}}$ & 4.2 & 3.7 & 4.3 & 0.98 & 0.696 & 0.166 \\
\hline Klebsiella ESA61 & 6.1 & 6 & 6.5 & 1.22 & 0.498 & 0.413 \\
\hline Klebsiella BAA1705 $5^{\mathrm{TM}}$ & 4.6 & 4.3 & 4.9 & 1.08 & 0.641 & 0.361 \\
\hline Candida albicans ESA109 & 15.4 & 15.7 & 14.5 & 4.72 & 0.13 & 0.72 \\
\hline C. albicans $60193^{\mathrm{TM}}$ & 12.6 & 12.5 & 11.2 & 3.43 & 0.121 & 0.37 \\
\hline DPPH & $45^{\mathrm{b}}$ & $73.3^{\mathrm{a}}$ & $27.5^{\mathrm{b}}$ & 36.5 & 0.006 & 0.001 \\
\hline ORAC & $260^{\mathrm{b}}$ & $327^{\mathrm{a}}$ & $247^{\mathrm{b}}$ & 91.5 & 0.076 & 0.026 \\
\hline Total phenolic & $12.6^{\mathrm{b}}$ & $16.2^{\mathrm{a}}$ & $12.2^{\mathrm{b}}$ & 5.15 & 0.239 & 0.049 \\
\hline Total flavonoid & $4^{\mathrm{ab}}$ & $4.9^{\mathrm{a}}$ & $2.6^{\mathrm{b}}$ & 2.92 & 0.295 & 0.048 \\
\hline Gallic acid & 0 & 0.15 & 0.07 & 0.35 & 0.485 & 0.485 \\
\hline Protocatechic acid & $0.07^{\mathrm{b}}$ & $0.15^{\mathrm{ab}}$ & $0.6^{\mathrm{a}}$ & 0.69 & 0.032 & 0.032 \\
\hline Catechin & 1.3 & 1.8 & 0.7 & 3.39 & 0.625 & 0.625 \\
\hline Chlorogenic acid & $1.9^{\mathrm{a}}$ & 0 & $1.3^{\mathrm{b}}$ & 2.17 & 0.04 & 0.04 \\
\hline Vanillic acid & 0.9 & 0.8 & 1.9 & 1.81 & 0.301 & 0.096 \\
\hline Caffeic acid & 0 & 0.4 & 0.1 & 0.72 & 0.338 & 0.338 \\
\hline Epicatechin & 0.2 & 0.3 & 0.2 & 0.51 & 0.711 & 0.711 \\
\hline$\beta$-Resorcylic acid & 5.7 & 42.9 & 11.9 & 59.3 & 0.177 & 0.178 \\
\hline Syringic acid & 1.3 & 0.7 & 0.2 & 2.3 & 0.356 & 0.356 \\
\hline$p$-Coumaric acid & $0.0^{\mathrm{b}}$ & $2.5^{\mathrm{a}}$ & $3^{\mathrm{a}}$ & 3.25 & 0.008 & 0.008 \\
\hline Ferulic acid & 0.2 & 1.6 & 0.2 & 2.61 & 0.263 & 0.263 \\
\hline Synapic acid & 0.01 & 0 & 0.01 & 0.04 & 0.559 & 0.559 \\
\hline Naringin & 0.5 & 1.5 & 0.5 & 1.96 & 0.227 & 0.227 \\
\hline Rutin & 6.2 & 8.8 & 26.4 & 33.5 & 0.182 & 0.118 \\
\hline Cinnamic acid & $0.6^{\mathrm{b}}$ & $4.4^{\mathrm{a}}$ & $1^{\mathrm{b}}$ & 4.84 & 0.053 & 0.045 \\
\hline Naringenin & $2.8^{\mathrm{b}}$ & $8.7^{\mathrm{ab}}$ & $24.9^{\mathrm{a}}$ & 45.7 & 0.052 & 0.039 \\
\hline Quercetin & $12.6^{\mathrm{a}}$ & $7.8^{\mathrm{ab}}$ & $3.5^{\mathrm{b}}$ & 13.8 & 0.178 & 0.038 \\
\hline Kaempferol & 4.4 & 8.2 & 1.1 & 14.7 & 0.375 & 0.375 \\
\hline
\end{tabular}

a Pooled standard deviation.

b Probability value for homoscedasticity using the Brown-Forsythe test ( $\mathrm{n}=3$ groups) or $F$-test ( 2 groups).

in the upper quadrants, the majority is in the upper right-hand quadrant ( $44 \%$ of the samples from this region). Therefore, there is a tendency for these samples to show a lower total phenolic content, antioxidant capacity, $\mathrm{a}^{*}, \mathrm{~b} *$ and $\mathrm{C}$ values and higher ash, $\mathrm{Ca}, \mathrm{Mg}$, chlorogenic acid, $\mathrm{L}^{*}$ and antimicrobial capacity values in comparison with the other regions, mainly compared to the SU. The averages of all variables for all Brazilian regions are given in Table 5 .

The distribution of the samples from the Central-West region (one in the upper left-hand quadrant and another in the lower right-hand quadrant) indicates that these products differ, especially in terms of the capacity to inhibit microorganisms. Samples from SE are mainly clustered in two quadrants (highlighted in Fig. 2A): the lower left-hand quandrant, where samples from SU containing Brassica pollen type (B) are also clustered (Fig. 2B), and the upper right-hand quadrant, where samples (both from SE and NE regions) with $C$. nucifera $(\mathrm{Cn})$ pollen type in its composition are grouped (Fig. 2B). This confirms that some samples from SE and samples containing B pollen have less potential to inhibit $S$. pyogenes as well as $S$. aureus strains.

In Fig. 2B, three clusters are highlighted. Samples with $\mathrm{Cn}$ pollen type have a clear tendency to have lower values of total phenolic content. In addition, there seems to be certain patterns in the data, indicating similar values of ash, $\mathrm{Ca}, \mathrm{Mg}$, chlorogenic acid, antioxidant capacity, $a^{*}, b^{*}, L^{*}$ and $C$ in these products. There also seems to be similarities in samples containing B pollen type; however, they differ in total phenolic content and antimicrobial capacity. This difference could be related to the presence of other pollen types and to the geographical 
Table 6

Statistical comparison between mono- and hetero-floral bee pollen samples from Brazil.

\begin{tabular}{|c|c|c|c|c|c|c|}
\hline Response variable & Monofloral $(\mathrm{n}=19)$ & Heterofloral $(n=37)$ & Relative difference (\%) & PSD $^{\mathrm{a}}$ & P-value ${ }^{b}$ & P-value ${ }^{c}$ \\
\hline Proteins & 16.3 & 14.9 & 8.4 & 6.17 & 0.403 & 0.436 \\
\hline Lipids & 7.5 & 6.7 & 11.8 & 1.97 & 0.068 & 0.111 \\
\hline Ashes & 3 & 2.9 & 1.7 & 1.97 & 0.219 & 0.622 \\
\hline $\mathrm{Ca}$ & 2.1 & 2.2 & 3.4 & 0.75 & 0.889 & 0.729 \\
\hline K & 6.7 & 6.6 & 1.7 & 1.16 & 0.388 & 0.737 \\
\hline $\mathrm{Mg}$ & 1.5 & 1.5 & 0.4 & 0.38 & 0.656 & 0.951 \\
\hline $\mathrm{Na}$ & 70.3 & 75.8 & 7.9 & 62.1 & 0.912 & 0.755 \\
\hline Zn & 70.6 & 69.8 & 1.1 & 15.9 & 0.199 & 0.865 \\
\hline $\mathrm{Fe}$ & 227 & 150 & 33.7 & 204 & 0.173 & 0.188 \\
\hline Mn & 79.1 & 101 & 27.6 & 61.1 & 0.359 & 0.207 \\
\hline $\mathrm{Cu}$ & 13.3 & 13.8 & 3.5 & 2.92 & 0.397 & 0.571 \\
\hline$L^{*}$ & 63.8 & 64.3 & 0.6 & 6.49 & 0.965 & 0.823 \\
\hline$a^{*}$ & 4.8 & 5.3 & 10 & 3.59 & 0.575 & 0.636 \\
\hline$b^{*}$ & 42.8 & 44.2 & 3.2 & 7.88 & 0.12 & 0.539 \\
\hline Chroma & 43.2 & 44.6 & 3.3 & 8.21 & 0.13 & 0.54 \\
\hline Streptococcus pyogenes ESA12 & 3.61 & 3.8 & 4.8 & 1.13 & 0.668 & 0.592 \\
\hline S. pyogenes $12344^{\mathrm{TM}}$ & 2.5 & 2.6 & 5.4 & 0.98 & 0.942 & 0.632 \\
\hline Staphylococcus aureus ESA 54 & 4.7 & 4.8 & 2.5 & 1.23 & 0.809 & 0.743 \\
\hline S. aureus $25923^{\mathrm{TM}}$ & 3.4 & 3.7 & 7.9 & 1.02 & 0.812 & 0.35 \\
\hline Escherichia coli ESA 72 & 5.2 & 5.5 & 6.5 & 1.15 & 0.448 & 0.306 \\
\hline E. coli $25922^{\mathrm{TM}}$ & 3.9 & 4.2 & 7.6 & 1.03 & 0.57 & 0.31 \\
\hline Klebsiella ESA61 & 6 & 6.3 & 4.1 & 1.26 & 0.366 & 0.489 \\
\hline Klebsiella BAA1705 $5^{\mathrm{m}}$ & 4.4 & 4.8 & 7.6 & 1.13 & 0.410 & 0.293 \\
\hline Candida albicans ESA109 & 15.1 & 15.1 & 0.1 & 4.75 & 0.494 & 0.995 \\
\hline C. albicans $60193^{\mathrm{TM}}$ & 11.8 & 12.1 & 2.4 & 3.47 & 0.412 & 0.774 \\
\hline DPPH & 52.4 & 41.6 & 20.7 & 35.9 & 0.237 & 0.288 \\
\hline ORAC & 280 & 269 & 3.7 & 90.7 & 0.242 & 0.688 \\
\hline Total phenolic & 14.7 & 12.8 & 13.2 & 5.07 & 0.537 & 0.176 \\
\hline Total flavonoid & 4 & 3.4 & 14.3 & 2.89 & 0.477 & 0.485 \\
\hline Gallic acid & 0 & 0.1 & NA & NA & NA & NA \\
\hline Protocatechic acid & 0.2 & 0.3 & 41.5 & 0.68 & 0.626 & 0.626 \\
\hline Catechin & 1.1 & 1.2 & 3.7 & 3.34 & 0.964 & 0.964 \\
\hline Chlorogenic acid & 0.7 & 1.4 & 94.5 & 2.16 & 0.254 & 0.254 \\
\hline Vanillic acid & 1.4 & 1.2 & 13.4 & 1.78 & 0.337 & 0.708 \\
\hline Caffeic acid & 0 & 0.2 & NA & NA & NA & NA \\
\hline Epicatechin & 0.2 & 0.2 & 9.9 & 0.5 & 0.869 & 0.869 \\
\hline$\beta$-Resorcylic acid & 33.2 & 9 & 72.8 & 58.3 & 0.143 & 0.143 \\
\hline Syringic acid & 1.1 & 0.5 & 54.1 & 2.27 & 0.371 & 0.371 \\
\hline$p$-Coumaric acid & 1.8 & 1.9 & 1.4 & 3.2 & 0.962 & 0.977 \\
\hline Ferulic acid & 1.1 & 0.2 & 78.1 & 2.56 & 0.222 & 0.222 \\
\hline Synapic acid & 0.01 & 0.01 & 39.5 & 0.04 & 0.787 & 0.787 \\
\hline Naringin & 0.6 & 0.8 & 20.4 & 1.93 & 0.815 & 0.815 \\
\hline Rutin & 8.9 & 19.4 & 117 & 33.5 & 0.325 & 0.274 \\
\hline Cinnamic acid & 1.9 & 1.8 & 5.5 & 4.82 & 0.939 & 0.939 \\
\hline Naringenin & 17.6 & 10.4 & 0.2 & 45 & 0.985 & 0.998 \\
\hline Quercetin & 9.2 & 6.6 & 28.4 & 13.6 & 0.412 & 0.5 \\
\hline Kaempferol & 6.8 & 2.4 & 64.5 & 14.5 & 0.287 & 0.287 \\
\hline
\end{tabular}

NA $=$ not applicable.

a Pooled standard deviation.

b Probability value for homoscedasticity using the $F$-test.

c Probability value obtained by Student's $t$-test for independent samples.

origin of the samples. Mărgăoan et al. (2014) used PCA and observed that bee pollen samples with the presence of Callendula officinalis, Taraxacum officinale and Anthylis sp. had high amounts of lutein, and bee pollen samples in which Brassica sp. was predominant had the highest amount of total lipids. Kostić et al. (2017), who also used a multivariate approach, observed that botanical origin influences the fatty acid composition of bee pollen. Therefore, it is possible to suggest that certain characteristics could be expected for bee pollen containing specific pollen types.

When one analyses Fig. 2C, one can see a greater dispersion of the $\mathrm{H}$ samples throughout the quadrants and groups of M samples (highlighted in the Figure), indicating that some monofloral bee pollen could have similarities, whereas the heterofloral samples could have many varied compositions. Comparison of the averages indicates a tendency of the $\mathrm{M}$ samples to contain higher Fe, $\beta$-resorcylic acid, syringic acid, ferulic acid, naringenin, quercetin, kaempferol and antioxidant capacity (DPPH) values. Furthermore, a trend towards higher Mn, chlorogenic acid and rutin content was observed in the $\mathrm{H}$ samples. The average values of all variables for $\mathrm{M}$ and $\mathrm{H}$ samples are shown in Table 6.

Using the contents of protein, iron, quercetin, total phenolic 


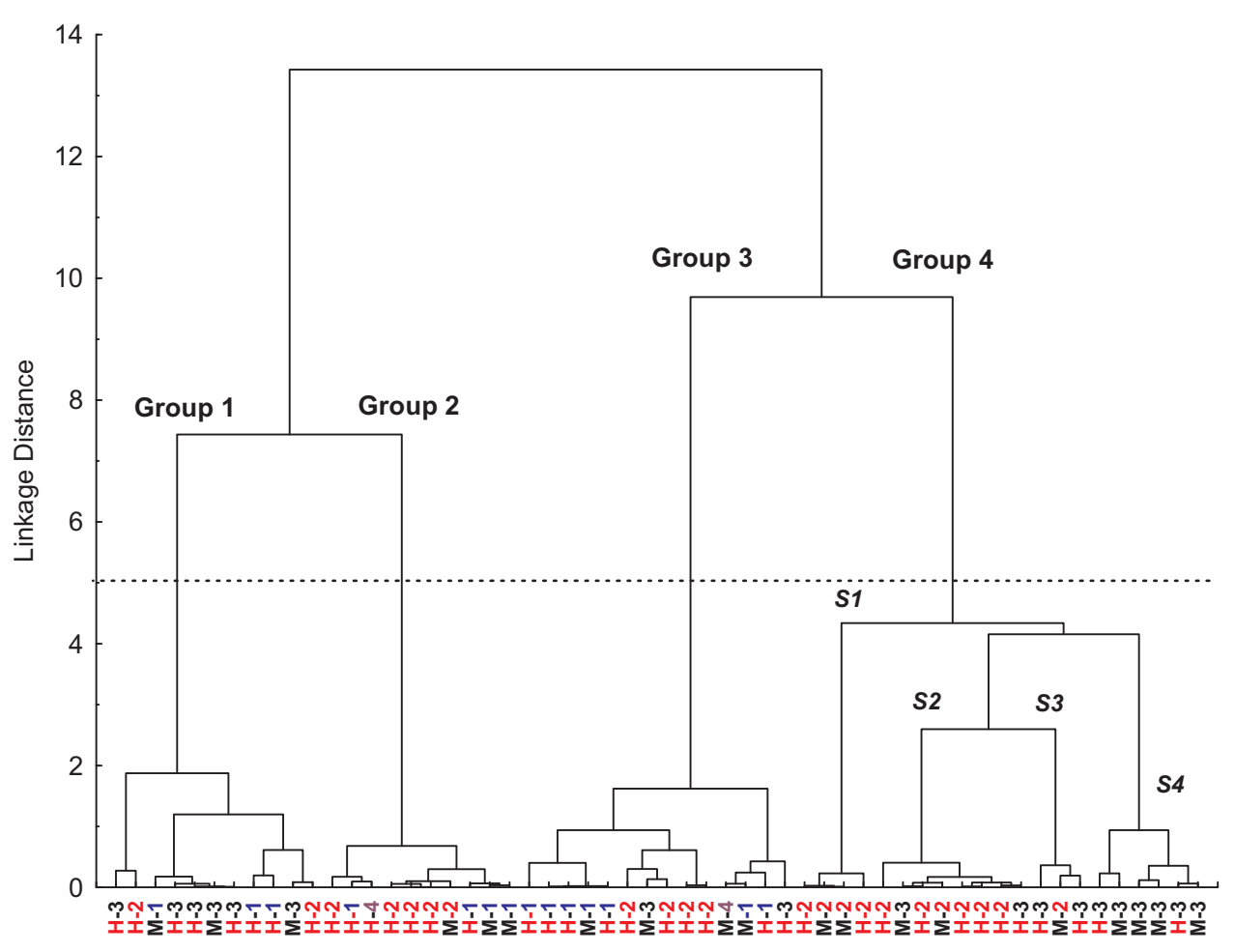

Fig. 3. Classification of the Brazilian bee pollen samples $(n=56)$ using hierarchical cluster analysis based on the content of protein, iron, quercetin, total phenolic compounds, antioxidant activity measured by ORAC, and inhibition of Staphylococcus aureus ESA54. 1 = Southern; 2 =Southeast; 3 = Northeast; $4=$ Central-West. $\mathrm{H}=$ heterofloral; $\mathrm{M}=$ monofloral. compounds, antioxidant activity measured by ORAC, and inhibition of S. aureus ESA 54 to classify the 56 bee pollen samples, HCA suggested 4 clusters (Fig. 3, Table 7). Similar antimicrobial capacity, naringin levels and instrumental colour parameters were observed in bee pollen in clusters 1 and 3; however, samples in cluster 1 showed the best combination of quercetin, antioxidant capacity and flavonoid content. This confirmed what has already been discussed: that there is a correlation between quercetin content and antioxidant capacity in the samples studied. Cluster 2 included the samples with lower $\mathrm{Zn}$ content and antimicrobial capacity against $S$. pyogenes $12344^{\mathrm{TM}}$, C. albicans ESA109 and C. albicans $60193^{\mathrm{TM}}$. Cluster 3 and 4 had similar $\mathrm{Ca}, \mathrm{K}, \mathrm{Mg}, \mathrm{Zn}$ and Mn values; however, protein, carbohydrate and cinnamic acid levels and inhibition of C. albicans $60193^{\mathrm{TM}}$ were higher in cluster 3. Intermediate values for antimicrobial capacity against $S$. pyogenes $12344^{\mathrm{TM}}$ and the lower values for $\mathrm{b}^{*}$ and $\mathrm{C}$ allowed discrimination of samples in cluster 4.

The number of monofloral bee pollen similar to each other was greater in cluster 4 , and the heterofloral samples were proportionally distributed throughout all clusters. Considering the geographical origin, there are no samples from SU in cluster 4; hence, the pollen collected in this region shows the characteristics of cluster 1,2 , or 3 . The samples from SE were distributed throughout all the groups, although $73 \%$ of them were in cluster 2 or 4 , suggesting a greater tendency to present characteristics related to these two groups. No bee pollen from NE was classified in cluster 2, and most of the samples (55\%) were included in cluster 4. Sattler et al. (2015) determined the protein, lipid, ash, glucose, fructose, ascorbic acid as well as $\alpha$-, $\beta$-, $\gamma$-, and $\delta$-tocopherol content in bee pollen samples produced in Southern Brazil and searched for similarities between the samples using HCA; however, the authors did not observe a clear distinction of the bee pollen samples according to the geographical origin.

\section{Conclusions}

Brazilian bee pollen has a variable composition related to its botanical and geographical origins. It contains high amounts of $\mathrm{Mn}, \mathrm{Fe}, \mathrm{Cu}$ as well as Zn; thus, bioavailability tests of these micronutrients should be carried out in a future study. The antioxidant capacity of this food is higher than that observed for fruits recognised as a dietary source of antioxidants; consequently, its consumption could be beneficial to human health. Phenolic compounds serve as potentially bioactive agents, especially quercetin, and rutin was the most frequent compound in the products. The phenolic compound profile of the $C$. nucifera bee pollen should be better studied, since this bee pollen type could have a species-specific profile. The antimicrobial capacity of the Brazilian bee pollen has been proven, and further studies should be done to identify which compounds act on the microorganisms and whether there are other strains that are more sensitive. The instrumental colour parameters are strong indicators of the presence of $\mathrm{Ca}, \mathrm{Mg}$ and $\mathrm{Fe}$ in Brazilian bee pollen; therefore, the simple and rapid determination of these parameters could be used to suggest the content of these minerals.

Bee pollen from Southern Brazil seems to have a higher biological potential; however, when one looks for bee pollen with higher $\mathrm{Ca}$ and $\mathrm{Mg}$ levels, products from the Northeast region should be prioritised, especially those with Cocos nucifera pollen type in its composition. In addition, it is possible to predict some information about bee pollen containing $C$. nucifera and bee pollen containing Brassica pollen type. Finally, similarities are more frequent in monofloral bee pollen than in heterofloral bee pollen, and when only a few nutritional value and biological potential indicators are used, the former stands out with respect to higher mineral content and because it is the less yellow food. 
Table 7

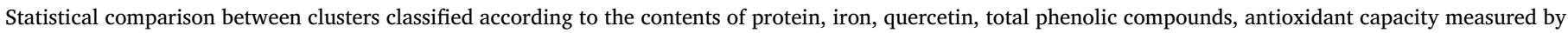
ORAC, and inhibition of Staphylococcus aureus ESA54 of 56 Brazilian bee pollen samples.

\begin{tabular}{|c|c|c|c|c|c|c|c|}
\hline Response variable & Cluster $1(n=11)$ & Cluster $2(n=10)$ & Cluster $3(n=14)$ & Cluster $4(\mathrm{n}=21)$ & PSD $^{\mathrm{a}}$ & P-value ${ }^{b}$ & P-value ${ }^{c}$ \\
\hline Proteins & $12.6^{\mathrm{b}}$ & $12.1^{\mathrm{b}}$ & $22.7^{\mathrm{a}}$ & $13.5^{\mathrm{b}}$ & 6.17 & 0.451 & $<0.001$ \\
\hline Lipids & 6.3 & 8 & 7.4 & 6.56 & 1.97 & 0.075 & 0.149 \\
\hline Ashes & $2.7^{\mathrm{b}}$ & $2.7^{\mathrm{b}}$ & $3.1^{\mathrm{a}}$ & $3^{\mathrm{ab}}$ & 0.36 & 0.176 & 0.02 \\
\hline $\mathrm{Ca}$ & $2.1^{\mathrm{ab}}$ & $1.8^{\mathrm{b}}$ & $2.3^{\mathrm{a}}$ & $2.4^{\mathrm{a}}$ & 0.74 & 0.375 & 0.153 \\
\hline $\mathrm{K}$ & $6.2^{\mathrm{ab}}$ & $5.9^{\mathrm{b}}$ & $6.9^{\mathrm{a}}$ & $7^{\mathrm{a}}$ & 1.16 & 0.397 & 0.038 \\
\hline $\mathrm{Mg}$ & $1.3^{\mathrm{b}}$ & $1.5^{\mathrm{ab}}$ & $1.8^{\mathrm{a}}$ & $1.6^{\mathrm{a}}$ & 0.38 & 0.423 & 0.015 \\
\hline $\mathrm{Na}$ & 93.8 & 56.4 & 53.5 & 85.6 & 62.1 & 0.131 & 0.245 \\
\hline $\mathrm{Zn}$ & $75.5^{\mathrm{a}}$ & $56.5^{\mathrm{b}}$ & $76.9^{\mathrm{a}}$ & $69.2^{\mathrm{a}}$ & 15.9 & 0.031 & 0.008 \\
\hline $\mathrm{Fe}$ & 94.9 & 205 & 132 & 235 & 204 & 0.098 & 0.228 \\
\hline Mn & $68.5^{\mathrm{b}}$ & $47.8^{\mathrm{b}}$ & $117^{\mathrm{a}}$ & $113^{\mathrm{a}}$ & 61.1 & 0.003 & 0.006 \\
\hline $\mathrm{Cu}$ & 14.7 & 13.5 & 13.7 & 13.1 & 2.92 & 0.695 & 0.559 \\
\hline $\mathrm{L}^{*}$ & $63.8^{\mathrm{ab}}$ & $58.9^{\mathrm{b}}$ & $65.6^{\mathrm{a}}$ & $65.8^{\mathrm{a}}$ & 6.49 & 0.572 & 0.032 \\
\hline$a^{*}$ & $5.8^{\mathrm{ab}}$ & $8^{\mathrm{a}}$ & $4.9^{\mathrm{b}}$ & $3.6^{\mathrm{b}}$ & 3.59 & 0.895 & 0.009 \\
\hline$b^{*}$ & $46.8^{\mathrm{ab}}$ & $51.5^{\mathrm{a}}$ & $43.5^{\mathrm{b}}$ & $38.6^{\mathrm{c}}$ & 7.88 & 0.034 & $<0.001$ \\
\hline Chroma & $47.2^{\mathrm{ab}}$ & $52.2^{\mathrm{a}}$ & $43.9^{b}$ & $38.8^{\mathrm{c}}$ & 8.2 & 0.036 & $<0.001$ \\
\hline$S p^{1}$ ESA12 & $3.1^{\mathrm{b}}$ & $4.7^{\mathrm{a}}$ & $2.9^{\mathrm{b}}$ & $4.1^{\mathrm{a}}$ & 1.13 & 0.762 & $<0.001$ \\
\hline$S p^{1} 12344^{\mathrm{TM}}$ & $2^{\mathrm{c}}$ & $3.5^{\mathrm{a}}$ & $1.9^{c}$ & $2.8^{\mathrm{b}}$ & 0.98 & 0.105 & $<0.001$ \\
\hline Sa1 ESA54 & $3.6^{\mathrm{b}}$ & $5.8^{\mathrm{a}}$ & $3.9^{\mathrm{b}}$ & $5.4^{\mathrm{a}}$ & 1.23 & 0.412 & $<0.001$ \\
\hline$S a^{1} 25923^{\text {тм }}$ & $3.1^{\mathrm{b}}$ & $4.3^{\mathrm{a}}$ & $2.9^{\mathrm{b}}$ & $4.1^{\mathrm{a}}$ & 1.02 & 0.979 & $<0.001$ \\
\hline$E c^{1}$ ESA72 & $4.8^{\mathrm{b}}$ & $6.4^{\mathrm{a}}$ & $4.4^{\mathrm{b}}$ & $5.9^{\mathrm{a}}$ & 1.15 & 0.843 & $<0.001$ \\
\hline$E c^{1} 25922^{\mathrm{TM}}$ & $3.6^{\mathrm{b}}$ & $4.7^{\mathrm{a}}$ & $3.2^{\mathrm{b}}$ & $4.7^{\mathrm{a}}$ & 1.03 & 0.281 & $<0.001$ \\
\hline$K^{1}$ ESA61 & $5.5^{\mathrm{b}}$ & $7.3^{\mathrm{a}}$ & $5.1^{\mathrm{b}}$ & $6.8^{\mathrm{a}}$ & 1.26 & 0.987 & $<0.001$ \\
\hline$K^{1}$ BAA $1705^{\text {тм }}$ & $4^{\mathrm{b}}$ & $5.3^{\mathrm{a}}$ & $3.9^{\mathrm{b}}$ & $5.2^{\mathrm{a}}$ & 1.13 & 0.112 & $<0.001$ \\
\hline $\mathrm{Ca}^{1}$ ESA109 & $14.3^{\mathrm{bc}}$ & $20.6^{\mathrm{a}}$ & $11.5^{\mathrm{c}}$ & $15.3^{\mathrm{b}}$ & 4.75 & 0.04 & $<0.001$ \\
\hline $\mathrm{Ca}^{1} 60193^{\mathrm{TM}}$ & $12^{\mathrm{b}}$ & $15.7^{\mathrm{a}}$ & $9.5^{\mathrm{c}}$ & $11.9^{\mathrm{b}}$ & 3.46 & 0.207 & $<0.001$ \\
\hline DPPH & $69.6^{\mathrm{a}}$ & $60.7^{\mathrm{a}}$ & $43.6^{\mathrm{ab}}$ & $26.3^{\mathrm{b}}$ & 35.9 & 0.052 & 0.003 \\
\hline ORAC & $362^{\mathrm{a}}$ & $331^{\mathrm{a}}$ & $244^{\mathrm{b}}$ & $218^{\mathrm{b}}$ & 90.7 & $<0.001$ & $<0.001$ \\
\hline Total phenolics & $16.5^{\mathrm{a}}$ & $19.5^{\mathrm{a}}$ & $11^{\mathrm{b}}$ & $10.6^{\mathrm{b}}$ & 5.07 & 0.156 & $<0.001$ \\
\hline Total flavonoids & $6.5^{\mathrm{a}}$ & $4.5^{\mathrm{ab}}$ & $2.8^{\mathrm{bc}}$ & $2.3^{\mathrm{c}}$ & 2.89 & 0.074 & $<0.001$ \\
\hline Gallic acid & 0 & 0 & 0.1 & 0.1 & 0.34 & 0.659 & 0.659 \\
\hline Protocatechic acid & 0.3 & 0.5 & 0.2 & 0.2 & 0.68 & 0.618 & 0.618 \\
\hline Catechin & 1.1 & 0.2 & 1.8 & 1.3 & 3.34 & 0.755 & 0.755 \\
\hline Chlorogenic acid & $0.5^{\mathrm{b}}$ & 0 & $2.4^{\mathrm{a}}$ & $1.4^{\mathrm{ab}}$ & 2.15 & 0.033 & 0.033 \\
\hline Vanillic acid & 1.2 & 1.7 & 0.6 & 1.6 & 1.78 & 0.258 & 0.337 \\
\hline Caffeic acid & 0 & 0.6 & 0.1 & 0 & 0.71 & 0.13 & 0.13 \\
\hline Epicatechin & 0.1 & 0.2 & 0.3 & 0.2 & 0.5 & 0.668 & 0.668 \\
\hline$\beta$-Resorcylic acid & 10.3 & 28.6 & 34.3 & 4.1 & 58.3 & 0.477 & 0.432 \\
\hline Syringic acid & 1.1 & 0.7 & 0 & 0.9 & 2.26 & 0.604 & 0.604 \\
\hline$p$-Coumaric acid & 1.1 & 2.2 & 2.9 & 1.4 & 3.19 & 0.491 & 0.485 \\
\hline Ferulic acid & 0.7 & 0.2 & 1.4 & 0.1 & 2.56 & 0.478 & 0.478 \\
\hline Synapic acid & 0 & 0 & 0 & 0.02 & 0.04 & NA & NA \\
\hline Naringin & $1.6^{\mathrm{a}}$ & $0.2^{\mathrm{b}}$ & $1.4^{\mathrm{a}}$ & $0.1^{\mathrm{b}}$ & 1.93 & 0.077 & 0.045 \\
\hline Rutin & 27.3 & 19.8 & 15.5 & 8.2 & 33.5 & 0.361 & 0.484 \\
\hline Cinnamic acid & 0 & $1.1^{\mathrm{b}}$ & $5.8^{\mathrm{a}}$ & $0.6^{\mathrm{b}}$ & 4.82 & 0.003 & 0.004 \\
\hline Naringenin & 11 & 16.7 & 5.7 & 29.5 & 45 & 0.421 & 0.454 \\
\hline Quercetin & $22.9^{\mathrm{a}}$ & $0.9^{\mathrm{b}}$ & $4.9^{\mathrm{b}}$ & $4.2^{\mathrm{b}}$ & 13.6 & $<0.001$ & $<0.001$ \\
\hline Kaempferol & 10.6 & 0.9 & 1.4 & 3.5 & 14.5 & 0.369 & 0.37 \\
\hline \multicolumn{8}{|l|}{ Classification } \\
\hline Monofloral & $3^{\mathrm{B}}$ & $3^{\mathrm{B}}$ & $4^{\mathrm{B}}$ & $9^{A}$ & 19 & & \\
\hline Hetofloral & $8^{\mathrm{A}}$ & $7^{\mathrm{A}}$ & $10^{\mathrm{A}}$ & $12^{\mathrm{A}}$ & 37 & & \\
\hline \multicolumn{8}{|l|}{ Geographical origin } \\
\hline Southern & $3^{\mathrm{A}}$ & $4^{\mathrm{A}}$ & $7^{\mathrm{A}}$ & 0 & 14 & & \\
\hline Southeast & $2^{\mathrm{B}}$ & $5^{\mathrm{A}}$ & $4^{\mathrm{B}}$ & $11^{\mathrm{A}}$ & 22 & & \\
\hline Northeast & $6^{\mathrm{AB}}$ & 0 & $2^{\mathrm{B}}$ & $10^{\mathrm{A}}$ & 18 & & \\
\hline Central-West & 0 & 1 & 1 & 0 & 2 & & \\
\hline
\end{tabular}

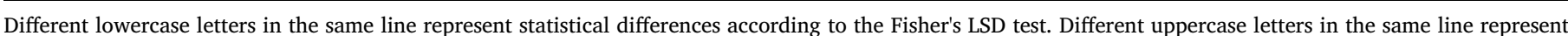
statistical differences according to the two-tailed multiple proportion Z-test.

${ }^{1}$ Sp: Streptococcus pyogenes; Sa: Staphylococcus aureus; Ec: Escherichia coli; K: Klebsiella; Ca: Candida albicans.

a Pooled standard deviation.

b Probability value for homoscedasticity.

c Probability value obtained by Student's $t$-test for two independent samples or by one-way ANOVA/Welch test; NA = not applicable. 


\section{Acknowledgements}

This study was funded by FAPESP (2011/51741-5). All authors are grateful to FAPESP for scholarships granted (2011/11746-8 and 2013/ 23179-6), to CNPq (304067/2013-0), and for the postdoctoral fellowship financed by POPH-QREN (SFRH/BPD/97049/2013). The authors are also grateful to beekeepers who provided samples.

\section{Conflict of interest}

The authors declare no conflict of interest.

\section{Appendix A. Supplementary material}

Supplementary data associated with this article can be found in the online version at doi:10.1016/j.fbio.2018.08.001.

\section{References}

AOAC - Association of Official Analytical Chemists (2005). Official Methods of Analysis of AOAC International - Methods 945.38 and 979.09 (16th ed.). Gaithersburg, MD, USA: AOAC International.

Almeida-Muradian, L. B., Arruda, V. A. S., \& Barreto, L. M. R. C. (2012). Manual de Controle de Qualidade do Pólen Apícola. São Paulo, SP, Brasil: Associação Paulista de Apicultores Criadores de Abelhas Melíferas Europeias (APACAME).

Aschemann-Witzel, J. (2015). Consumer perception and trends about health and sustainability: Trade-offs and synergies of two pivotal issues. Current Opinion in Food Science, 3, 6-10.

Barth, O. M., Freitas, A. S., Oliveira, E. S., Silva, R. A., Maester, F. M., Andrella, R. R. S., \& Cardozo, G. M. B. Q. (2010). Evaluation of the botanical origin of commercial dry bee pollen load batches using pollen analysis: A proposal for technical standardization. Anais da Academia Brasileira de Ciências, 82, 893-902.

Barth, O. M. (1970a). Análise microscópica de algumas amostras de mel. 1. pólen dominante. Anais da Academia Brasileira de Ciências, 42, 351-366.

Barth, O. M. (1970b). Análise microscópica de algumas amostras de mel. 2. pólen acessório. Anais da Academia Brasileira de Ciências, 42, 571-590.

Barth, O. M. (1970c). Análise microscópica de algumas amostras de mel. 3. pólen isolado. Anais da Academia Brasileira de Ciências, 42, 747-772.

Barth, O. M. (1989). O Pólen no Mel Brasileiro. Rio de Janeiro, RJ, Brasil: Luxor.

Bogdanov, S. (2012). The Bee Pollen Book: Chapter 1. Internet: 〈http://www.bee-hexagon. net>. (Accessed 15 February 2013).

Brand-Williams, W., Cuvelier, M. E., \& Berset, C. (1995). Use of a free radical method to evaluate antioxidant. Food Science and Technology, 28, 25-30.

Campos, M. G. R., Almaraz-Abarca, N., Matos, M. P., Gomes, N. M., Arruda, V. A., \& Barth, O. M. (2015). Zea mays L. pollen: An approach to its quality control. Journal of Agricultural Science and Technology B, 5, 513-522.

Campos, M. G. R., Bogdanov, S., Almeida-Muradian, L. B., Szczesna, T., Mancebo, Y., Frigerio, C., \& Ferreira, F. (2008). Pollen composition and standardisation of analytical methods. Journal of Apicultural Research and Bee World, 47, 156-163.

Carpes, S. T., Prado, A., Moreno, I. A. M., Mourão, G. B., Alencar, S. M., \& Masson, M. L. (2008). Avaliação do potencial antioxidante do pólen apícola produzido na Região Sul do Brasil. Química Nova, 31, 1660-1664.

De-Melo, A. A. M., \& Almeida-Muradian, L. B. (2017). Chemical composition of bee pollen. In J. M. Alvarez-Suarez (Ed.). Bee products - Chemical and biological properties (pp. 221-259). Berlin: Springer.

De-Melo, A. A. M., Estevinho, L. M., Moreira, M. M., Delerue-Matos, C. Freitas, A. S. Barth, O. M., \& Almeida-Muradian, L. B. (2018). Phenolic profile by HPLC-MS, biological potential and nutritional value of a promising food: Monofloral bee pollen. Journal of Food Biochemistry, e12536.

De-Melo, A. A. M., Estevinho, L. M., Sattler, J. A. G., Souza, B. R., Freitas, A. S., Barth, O. M., \& Almeida-Muradian, L. B. (2016). Effect of processing conditions on characteristics of dehydrated bee-pollen and correlation between quality parameters. LWT - Food Science and Technology, 65, 808-815.

Granato, D., Calado, V. M. A., \& Jarvis, B. (2014). Observations on the use of statistical methods in food science and technology. Food Research International, 55, 137-149.

Heim, K. E., Tagliaferro, A. R., \& Bobilya, D. J. (2002). Flavonoid antioxidants: Chemistry, metabolism and structure-activity relationships. Journal of Nutritional Biochemistry, 13, 572-584.

Huang, D., Ou, B., \& Prior, R. L. (2005). The chemistry behind antioxidant capacity assays. Journal of Agricultural and Food Chemistry, 53, 1841-1856.

Institute of Medicine (1997). Dietary reference intakes for calcium, phosphorus, magnesium, vitamin D, and fluoride. Washington, DC: The National Academies Press (ISBN-10: 0309-06403-1).

Institute of Medicine (2001). Dietary reference intakes for vitamin A, vitamin K, arsenic, boron, chromium, copper, iodine, iron, manganese, molybdenum, nickel, silicon, vanadium, and zinc. Washington, DC: The National Academies Press (ISBN-10: 0-30907290-5).

Institute of Medicine (2005). Dietary reference intakes for water, potassium, sodium, chloride, and sulfate. Washington, DC: The National Academies Press (ISBN: 0-309-53049-0). Institute of Medicine (2011). Dietary reference intakes for calcium and vitamin D. Washington, DC: The National Academies Press (ISBN: 978-0-309-16395-8).

Kaskoniené, V., \& Venskutonis, P. R. (2010). Floral markers in honey of various botanical and geographic origins: A review. Comprehensive Reviews in Food Science and Food Safety, 9, 620-634.

Komosinska-Vassev, K., Olczyk, P., Kafmierczak, J., Mencner, L., \& Olczyk, K. (2015). Bee pollen: Chemical composition and therapeutic application. Evidence-Based Complementary and Alternative Medicine, 2015, 1-6.

Kostić, A. Z., Pešić, M. B., Trbović, D., Petronijević, R., Dramićanin, A. M., MilojkovićOpsenica, D. M., \& Tešić, Z. L. (2017). The fatty acid profile of Serbian bee-collected pollen - a chemotaxonomic and nutritional approach. Journal of Apicultural Research, 56, 533-542.

Leblanc, B. W., Davis, O. K., Boue, S., Delucca, A., \& Deeby, T. (2009). Antioxidant activity of Sonoran Desert bee pollen. Food Chemistry, 115, 1299-1305.

Lorenzi, H. (2000). Plantas Daninhas do Brasil (3th ed.). Nova Odessa, SP, Brasil: Instituto Plantarum de Estudos da Flora Ltda.

Malavolta, E., Vitti, G. C., \& Oliveira, S. A. (1997). Avaliação do Estado Nutricional das Plantas: Princípios e Aplicações (2nd ed.). Piracicaba, SP, Brasil: Associação Brasileira para Pesquisa da Potassa e do Fosfato.

Mărgăoan, R., Mărghitaş, L. A., Dezmirean, D. S., Dulf, F. V., Bunea, A., Socaci, S. A., \& Bobis, O. (2014). Predominant and secondary pollen botanical origins influence the carotenoid and fatty acid profile in fresh honeybee-collected pollen. Journal of Agricultural and Food Chemistry, 62, 6306-6316.

Mensor, L. L., Menezes, F. S., Leitão, G. G., Reis, A. S., Santos, T. C., Coube, C. S., \& Leitão, S. G. (2001). Screening of Brazilian plant extracts for antioxidant activity by the use of DPPH free radical method. Phytotheraphy Research, 15, 127-130.

Modro, A. F. H., Silva, I. C., Luz, C. F. P., \& Message, D. (2009). Analysis of pollen load based on color, physicochemical composition and botanical source. Anais da Academia Brasileira de Ciências, 81, 281-285.

Mohdaly, A. A. A., Mahmoud, A. A., Roby, M. H. H., Smetanska, I., \& Ramadan, M. F. (2015). Phenolic extract from propolis and bee pollen: Composition, antioxidant and antibacterial activities. Journal of Food Biochemistry, 39, 538-547.

Morais, M., Moreira, L., Feás, X., \& Estevinho, L. M. (2011). Honeybee-collected pollen from five Portuguese Natural Parks: Palynological origin, phenolic content, antioxidant properties and antimicrobial activity. Food and Chemical Toxicology, 49, 1096-1101.

Moreti, A. C. C. C., Marchini, L. C., Souza, V. C., \& Rodrigues, R. R. (2002). Atlas do Pólen de Plantas Apícolas. Janeiro, RJ, Brasil: Papel Virtual.

Morgano, M. A., Martins, M. C. T., Rabonato, L. C., Milani, R. F., Yotsuyanagi, K., \& Rodriguez-Amaya, D. B. (2010). Inorganic contaminants in bee pollen from southeastern Brazil. Journal of Agricultural and Food Chemistry, 58, 6876-6883.

Morgano, M. A., Martins, M. C. T., Rabonato, L. C., Milani, R. F., Yotsuyanagi, K., \& Rodriguez-Amaya, D. B. (2012). A comprehensive investigation of the mineral composition of brazilian bee pollen: Geographic and seasonal variations and contribution to human diet. Journal of the Brazilian Chemical Society, 23, 727-736.

Nogueira, C., Iglesias, A., Feás, X., \& Estevinho, L. M. (2012). Commercial bee pollen with different geographical origins: A comprehensive approach. International Journal of Molecular Sciences, 13, 11173-11187.

Pascoal, A., Rodrigues, S., Teixeira, A., Féas, X., \& Estevinho, L. M. (2014). Biological activities of commercial bee pollens: Antimicrobial, antimutagenic, antioxidant and anti-inflammatory. Food and Chemical Toxicology, 63, 233-239.

Rubilar, M., Pinelo, M., Shene, C., Sineiro, J., \& Nuñez, M. J. (2007). Separation and HPLC-MS identification of phenolic antioxidants from agricultural residues: Almond hulls and grape pomace. Journal of Agricultural and Food Chemistry, 55, 10101-10109.

Sattler, J. A. G., De-Melo, A. A. M., Nascimento, K. S., Melo, I. L. P., Mancini-Filho, J., Sattler, A., \& Almeida-Muradian, L. B. (2016). Essential minerals and inorganic contaminants (barium, cadmium, lithium, lead and vanadium) in dried bee pollen produced in Rio Grande do Sul State, Brazil. Food Science and Technology, 36 505-509.

Sattler, J. A. G., Melo, I. L. P., Granato, D., Araújo, E., Freitas, A. S., Barth, O. M., Almeida-Muradian, L. B. (2015). Impact of origin on bioactive compounds and nutritional composition of bee pollen from southern Brazil. Food Research International, 77, 82-91.

Ulusoy, E., \& Kolayli, S. (2014). Phenolic composition and antioxidant properties of anzer bee pollen. Journal of Food Biochemistry, 38, 73-82.

United States Department of Agriculture (2010). Database for the Oxygen Radical Absorbance Capacity (ORAC) of Selected Foods, Release 2. Internet: 〈http://www. orac-info-portal.de/download/ORAC_R2.pdf . (Accessed 24 September 2015).

University of Campinas (2006). Tabela Brasileira de Composição de Alimentos. Internet: 〈http://www.unicamp.br/nepa/taco〉. (Accessed 13 May 2013).

Vit, P., \& Santiago, B. (2008). Composición química de polen apícola fresco recolectado en el páramo de Misintá de los andes venezolanos. Archivos Latinoamericanos de Nutricion, 58, 411-415.

World Health Organization (2012). Guideline: Sodium intake for adults and children. Geneva, Switzerland: World Health Organization (ISBN: 9789241504836).

Yang, K., Wu, D., Ye, X., Liu, D., Chen, J., \& Sun, P. (2013). Characterization of chemical composition of bee pollen in China. Journal of Agricultural and Food Chemistry, 61 $708-718$.

Zielinski, A. A. F., Haminiuk, C. W. I., Nunes, C. A., Schnitzler, E., van Ruth, S. M., \& Granato, D. (2014). Chemical composition, sensory properties, provenance, and bioactivity of fruit juices as assessed by chemometrics: A critical review and guideline. Comprehensive Reviews in Food Science and Food Safety, 13, 300-316. 